This item was submitted to Loughborough's Research Repository by the author.

Items in Figshare are protected by copyright, with all rights reserved, unless otherwise indicated.

\title{
Importance of intervertebral displacement for whiplash investigations
}

PLEASE CITE THE PUBLISHED VERSION

https://doi.org/10.1080/13588265.2019.1594548

PUBLISHER

(C) Taylor \& Francis

VERSION

AM (Accepted Manuscript)

PUBLISHER STATEMENT

This is an Accepted Manuscript of an article published by Taylor \& Francis in International Journal of Crashworthiness on 7 May 2019, available online:

http://www.tandfonline.com/10.1080/13588265.2019.1594548.

\section{LICENCE}

CC BY-NC-ND 4.0

\section{REPOSITORY RECORD}

Bumberger, Roman, Memis Acar, and Kaddour Bouazza-Marouf. 2019. "Importance of Intervertebral Displacement for Whiplash Investigations". Loughborough University. https://hdl.handle.net/2134/37330. 


\title{
Importance of Intervertebral Displacement for Whiplash Investigations
}

\author{
Roman Bumberger, Memis Acar and Kaddour Bouazza-Marouf \\ School of Mechanical, Electrical and Manufacturing Engineering, Loughborough University, UK \\ r.bumberger@lboro.ac.uk,m.acar@lboro.ac.uk, k.bouazza-marouf@lboro.ac.uk
}

\begin{abstract}
It is often reported that the physiological rotational limits of adjacent vertebrae in the cervical spine are exceeded in rear-end accidents which play a significant role in Whiplash Associated Disorders (WAD). This paper presents the first analysis of existing experimental and computational intervertebral displacement research. Existing techniques to capture intervertebral displacement in experimental studies can be grouped into three methods: visual targets method, electronic sensors method and $X$-Ray method. The analysis of intervertebral displacements has led to the development of the intervertebral neck injury criterion (IV-NIC); it has also shown an upward shift of the C5C6 instantaneous axis of rotation and that the flexion changes to extension point between $\mathrm{C} 2$ and $\mathrm{C} 4$. Furthermore, it is also shown that when a computational model is validated only for the head kinematics, it should not be assumed that the model provides good neck kinematics. Lastly, current rear-impact dummies are incapable of providing true neck kinematics.
\end{abstract}

Keywords: Whiplash, rear-end, intervertebral, segmental, displacement, motion

\section{NOTATION}

$\begin{array}{ll}A T D & \text { Anthropomorphic Test Device } \\ C 1-C 7 & \text { Cervical vertebrae 1 to } 7 \\ I A R & \text { Instantaneous Axis of Rotation } \\ I V-N I C & \text { Intervertebral Neck Injury Criterion } \\ M F R & \text { Muscle Force Replication } \\ N Z & \text { Neutral Zone } \\ P M H S & \text { Post Mortem Human Subject } \\ R O M & \text { Range of Motion } \\ T 1 & \text { First thoracic vertebra } \\ W C S & \text { Whole Cervical Spine }\end{array}$

\section{INTRODUCTION}

Whiplash Associated Disorders (WAD) is a general term used to describe minor injuries to the neck, mostly as a result of a rear-end motor vehicle collision. There is a wide range of medical conditions and symptoms for WAD, most typical are dizziness, neck pain and neck stiffness (especially in the posterior area), blurred vision, tenderness over the neck muscles, reduced and painful neck movements, headaches (often in the occipital region), shoulder pain, concentration difficulties and others [1-5]. Although these symptoms are minor, the long-term symptoms to the occupants result in high costs to the economy, to healthcare services and to individuals [6]. Furthermore, whiplash injuries are difficult to detect since diagnostic tools such as X-Rays, Computed Tomography (CT) or Magnetic Resonance Imaging (MRI) scans are not able to identify the location or the extent of the injury [7]. Also the injury mechanisms are not fully understood; WAD may be a combination of several injury types in the neck, such as in muscles, ligaments, facet joints, intervertebral discs or nerve tissues [8].

Even though the fatality risk for rear-end impacts is low, they are a frequent source of injury [9]. In the National Highway Traffic Safety Administration (NHTSA) report for the year 2014 [10] it is reported that while rear-end accidents contribute to only $6.6 \%$ of fatal accidents, they result in almost a third $(31.7 \%)$ of all injuries. These percentages are similar to previous NHTSA reports $(2001,2005)$ and show the same trend as accident reports from other countries [6, 11, 12]. In addition, for autonomous driving vehicles rear-end accidents are even more important. Favarò et al. [13] concluded that selfdriving vehicles can lower the accident rate for all other accident types except for rear-end impacts, which were found to be two thirds of the total number of impacts in autonomous driving vehicles. Carlsson [6] summarized different studies and concluded that around 50\% of whiplash injuries are 
related to rear impacts. Therefore, it is expected that preventing WAD will be even more important in the future, i.e. adequate passive occupant protection is required.

The first step of passive occupant safety to minimize WAD was the introduction of head-restraints in the 1950s, and in 1969 these were made mandatory equipment for new cars in the US [14]. However, WAD still continues to be a regular complaint after rear-end impacts. Therefore, it has been suggested that injuries occur before the neck reaches full hyperextension [15]. This suggestion is supported by human volunteer experiments; many volunteers reported neck complaints after rear-end impact experiments, although no hyperextension of the head occurred because of the head restraint used in the experiments [16-18]. Consequently, it is also important to adequately balance as many crash related properties as possible, such as vehicle stiffness, state of rigidity of the interior padding including objects surrounding the occupants, effectiveness of restraint systems and others [19]. This can be achieved by active head-restraints (e.g. Acar et al. [20]), optimizing material properties of head restraints (e.g. Schmitt et al. [21]), novel head-restraint systems (e.g. Latchford et al. [22]), research for the influence of sitting position (e.g. Latchford et al. [23]) and/or energy absorbing car seats (e.g. Himmetoglu [24]).

Although the exact injury mechanism is still not agreed on, there is a reasonable good agreement that the unnatural deformation of the cervical spine in the retraction phase causes injury [25]; at this stage the head is not even behind its physiological limit [7]. Panjabi et al. [26] hypotheses that a neck injury occurs during whiplash when the relative displacement between vertebrae significantly exceeds the physiological limits; such an exceeding of physiologic limits indicates high impact loads which can be associated with the potential to injure ligamentous tissue, annulus fibres, and facet joints [27]. These exceeding of physiologic limits can occur between two adjacent vertebrae without the gross head-neck kinematics exceeding their limits [28]. Intervertebral motions are more detailed kinematics than gross head-neck kinematics. There have been also clinical observations reported which support the hypothesis of soft tissue injury, i.e. damage of facet joints [29-32] and intervertebral discs [32-34] have been stated by whiplash patients and documented during post-mortem evaluations. Kang et al. [32] reports for their PMHS study that injuries could not be detected by imaging or palpation but could only be identified in autopsy; however, these injuries can likely result in neck pain in a live occupant. Consequently, excessive intervertebral motion may explain the clinical observations reported for whiplash accidents. This illustrates the importance of intervertebral displacements during rear-end impacts.

The first study investigating intervertebral rotations was performed at Yale University School of Medicine [28]. They used six cervical specimens and measured the physiological Range of Motion (ROM) for each joint, then, they conducted rear-end impact tests and recorded the intervertebral rotations. Comparing these static and dynamic rotations resulted in two conclusions: first, in the retraction phase the intervertebral rotations between two adjacent vertebrae were higher than during the hyperextension phase of the head, and second, the peak values of the intervertebral rotations were greater than the measured physiological ROM values determined in the same study prior to the trauma tests. It was found that the lower cervical spine is during the retraction phase at a higher risk than the upper cervical spine, as intervertebral rotations for C6-C7 and for C7-T1 exceeded ROM for all six specimens at all different impact speeds $(2.5 \mathrm{~g}, 4.5 \mathrm{~g}, 6.5 \mathrm{~g}, 8.5 \mathrm{~g})$, although the gross head extension is close to zero. To explain this phenomenon, the researchers stated that in the retraction phase the spine forms a S-shape, in which the flexion of the upper cervical spine has to be compensated for by additional extension in the lower cervical spine. Also Panjabi et al. [26] conducted similar PMHS experiments; by comparing the cervical flexibility before and after dynamic loading an increase in ROM was observed, indicating that some anatomic structure must have been damaged.

A tool which is frequently used in whiplash sled testing are Anthropomorphic Test Devices (ATD), in particular BioRID II. The neck of which consists of seven cervical vertebrae and an Occipital Condyle plate. The C4 vertebra can accept a two-axis accelerometer block. Pin joints are used to connect the vertebrae in ATDs; therefore, intervertebral translation movements (compression/tension/shear of the 
spine) are not possible. Hence, such devices are not capable of intervertebral translational displacement investigations. In addition, ATDs are normally not equipped with intervertebral rotational sensors [35]. However, the biofidelity of the ATD has been evaluated by several researchers, but most of these evaluations have focused on global (gross) motions, i.e. head and T1 kinematics, rather than comparing intervertebral rotations of cervical vertebrae $[25,35]$. The evaluation of the global (gross) motions was done with the aid of reference data obtained from volunteer and/or PMHS sled experiments. The evaluation of intervertebral rotations is challenging because available reference data is limited, however, the first study which evaluates the intervertebral rotations of the BioRID II against PHMS sled experiments under identical crash conditions was done by Kang et al. [25]. The BioRID II neck was equipped with angular rate sensors for each vertebra on the lateral aspect of the cervical column (C1 to $\mathrm{C} 7$ ). Reference data were obtained from PHMS equipped with three angular rate sensors and three accelerometers were attached to each vertebra ( $\mathrm{C} 2$ to $\mathrm{C} 7)$. Rear-end sled experiments on the PMHS and a BioRID II were performed under the same test conditions. For experiments with a speed-change of $17 \mathrm{~km} / \mathrm{h}$ the BioRID II shows comparable results to the PMHS, but by a speed change of $24 \mathrm{~km} / \mathrm{h}$ the cervical vertebrae of the BioRID II show not enough rearward rotation. This study used an experimental seat, while the follow-up study [35] uses a more realistic production seat. The conclusion of the studies by Kang et al. [25, 35] is that the biofidelity of the BioRID II spine in flexion could be improved in terms of range of motion as well as in stiffness.

In the current paper the authors focus on the importance of intervertebral displacement for whiplash investigations. This is accomplished by analysing publications in the public domain on experimental intervertebral displacement data, by summarising techniques used to capture such data in rear-end impact experiments as well as by analysing some computational models which were validated at intervertebral level. This is important as a computation model can have head kinematics which show very good agreement to experimental data, although the neck segmental kinematics agrees poorly [36]. Methods and their respective limitations in evaluating intervertebral motion are also presented and discussed.

Therefore, it is important to analyse intervertebral displacements in rear-end impacts to augment the understanding of resulting whiplash injuries. This paper presents the first analysis of existing experimental and computational intervertebral displacement research, showing the importance of such field of research.

\section{METHODS TO EXPERIMENTALY MEASURE INTERVERTEBRAL DISPLACEMENT}

In general there have been three typical subject types utilised for whiplash investigations, namely, full body Post Mortem Human Subject (PMHS), PMHS cervical spine specimen and volunteers. An obvious limitation of all PMHS studies is the lack of muscle activity, which may affect the kinematics of the neck [36]; another limitation is that often elderly PMHSs are used [32]. Furthermore, in experiments using cervical spine PMHS specimens the first thoracic vertebra (T1) is often restricted to horizontal motion only. Thus the vertical and rotational motions of T1, e.g. due to ramping and/or straightening of the thoracic spine [37] are often not included in such experiments, but these motions have been observed in volunteer and full body PMHS rear-end tests. Another issue with using cervical spine PMHS specimens is that muscles are either completely removed [28] or are replaced with artificial muscle replicas [38]. On the other hand, the advantage of PMHS experiments is that injury hazards are not a concern, unlike to volunteer experiments where the safety of the subjects and ethical issues are main limitations, for example the impact severity and the attachment of instrumentation devices on volunteers.

In general there have been three different methods utilised to capture the intervertebral displacement during rear-end impacts: (i) the method of tracking visual targets mounted on the vertebrae; (ii) collection of data using accelerometer sensors or angular rate sensors mounted on the vertebrae and (iii) 
high speed lateral X-ray video images. Table 1 summarises some details of these methods and full explanation of the content is given below.

First, the method of tracking of visual targets on the vertebrae is considered. Obviously, in order to attach a visual target on a vertebra the integrity of the neck has to be compromised, consequently this method is only suitable for full body PMHS or for PMHS cervical spine specimen. For PMHS cervical spine specimen often all neck muscles are removed completely [28, 43], but sometimes artificial muscle force replacements are used to simulate muscle behaviour $[26,38,58]$. However, this method allows attaching the visual targets directly on the vertebrae, but the effect on the neck behaviour due to the loss of soft tissue is not quantified. The PMHS cervical spine specimen often used only a horizontal T1 acceleration; therefore the $\mathrm{T} 1$ vertical displacement and the $\mathrm{T} 1$ rotation are most often ignored. The full body PMHS has the advantage that lateral neck muscles do not have to be removed from the neck as the visual target is not mounted directly on a vertebra. A beam passing laterally through the neck is attached to the vertebra body and a visual target is mounted at the end of the beam $[45,46]$. However, such a lateral beam adds weight to the vertebrae and the beam may influence the soft tissue behaviour. Furthermore, the considerable length of the beam (the exact length was not published), is not favourable

Table 1: Different methods used to capture intervertebral displacement in rear-end experiments.

\begin{tabular}{|c|c|c|c|c|c|c|}
\hline $\begin{array}{l}\text { Measuring } \\
\text { Method }\end{array}$ & $\begin{array}{l}\text { Typically } \\
\text { applied to }\end{array}$ & $\begin{array}{c}\text { Neck integrity modification } \\
\text { and effect of } \\
\text { instrumentation }\end{array}$ & Measurement & $\begin{array}{l}\text { Data } \\
\text { Acquisition } \\
\text { Rate }\end{array}$ & $\begin{array}{l}\text { Data Collection } \\
\text { Efficacy }\end{array}$ & Studies \\
\hline \multirow{2}{*}{$\begin{array}{l}\text { Tracking of } \\
\text { visual } \\
\text { targets }\end{array}$} & $\begin{array}{c}\text { PMHS } \\
\text { cervical } \\
\text { specimen - } \\
\text { Visual targets } \\
\text { on vertebrae }\end{array}$ & $\begin{array}{l}\text { High - (lateral neck elements } \\
\text { need to be removed for a } \\
\text { clear view on vertebrae, i.e. } \\
\text { at least the lateral muscles } \\
\text { and skin need to be removed. } \\
\text { Muscle force replications can } \\
\text { be used) }\end{array}$ & Absolute & $\begin{array}{c}\text { Medium } \\
\text { (approx. } 1 \mathrm{kHz} \text { ) }\end{array}$ & $\begin{array}{l}\text { Medium (Limitations are } \\
\text { the camera resolution } \\
\text { and its position) }\end{array}$ & {$[1,3,28,39-44]$} \\
\hline & $\begin{array}{l}\text { Full body } \\
\text { PMHS - } \\
\text { visual targets } \\
\text { on vertebrae } \\
\text { via lateral } \\
\text { beams } \\
\text { through the } \\
\text { neck }\end{array}$ & $\begin{array}{l}\text { Medium (lateral beams pass } \\
\text { through neck; i.e. there is } \\
\text { added weight to vertebrae } \\
\text { and the neck integrity is } \\
\text { damaged. Tissue behaviour } \\
\text { could be influenced) }\end{array}$ & Absolute & $\begin{array}{c}\text { Medium } \\
\text { (approx. } 1 \mathrm{kHz} \text { ) }\end{array}$ & $\begin{array}{l}\text { Medium (Limitations are } \\
\text { the camera resolution } \\
\text { and its position) }\end{array}$ & {$[45,46]$} \\
\hline $\begin{array}{l}\text { Accelerome } \\
\text { ters / } \\
\text { Angular } \\
\text { Rate Sensor } \\
\text { (2D or 3D) } \\
\text { on each } \\
\text { vertebrae }\end{array}$ & $\begin{array}{l}\text { Full body } \\
\text { PMHS }\end{array}$ & $\begin{array}{l}\text { Medium (sensors have to be } \\
\text { mounted on vertebrae, i.e. } \\
\text { there is added weight to } \\
\text { vertebrae. The neck integrity } \\
\text { is damaged. Tissue } \\
\text { behaviour could be } \\
\text { influenced) }\end{array}$ & $\begin{array}{l}\text { Relative (initial } \\
\text { configuration of } \\
\text { the neck need } \\
\text { to be measured) }\end{array}$ & $\begin{array}{l}\text { High (approx. } \\
20 \mathrm{kHz} \text { ) }\end{array}$ & $\begin{array}{l}\text { High (Displacement data } \\
\text { is determined from } \\
\text { double integration of the } \\
\text { accelerometer data) }\end{array}$ & {$[25,32,47]$} \\
\hline \multirow{2}{*}{$\begin{array}{l}\text { Lateral X- } \\
\text { Ray scan }\end{array}$} & $\begin{array}{l}\text { Full body } \\
\text { PMHS - with } \\
\text { or without } \\
\text { added } \\
\text { vertebrae } \\
\text { markers }\end{array}$ & $\begin{array}{l}\text { Low or None ( no vertebrae } \\
\text { instrumentation is necessary, } \\
\text { however metal markers can } \\
\text { be added to vertebrae for } \\
\text { better visibility) }\end{array}$ & Absolute & $\begin{array}{c}\text { Low (approx. } \\
200 \mathrm{~Hz} \text { ) }\end{array}$ & $\begin{array}{l}\text { Low (Limited field of } \\
\text { view and not all } \\
\text { vertebrae can be } \\
\text { tracked) }\end{array}$ & {$[15,48-51]$} \\
\hline & $\begin{array}{l}\text { Human } \\
\text { volunteers - } \\
\text { without } \\
\text { added } \\
\text { vertebrae } \\
\text { markers }\end{array}$ & $\begin{array}{l}\text { Very low (no vertebrae } \\
\text { instrumentation is possible; } \\
\text { however, global } \\
\text { instrumentation will be still } \\
\text { used) }\end{array}$ & Absolute & $\begin{array}{l}\text { Very low }(<90 \\
\text { Hz due to } \\
\text { radiation } \\
\text { hazard })\end{array}$ & $\begin{array}{l}\text { Very low (Limited field } \\
\text { of view and not all } \\
\text { vertebrae can be } \\
\text { tracked) }\end{array}$ & {$[17,18,52-57]$} \\
\hline
\end{tabular}


to capture precise intervertebral motion. To quantify the effect of the PMHS preparation, Geigl et al. (1994) performed two experiments using the same PMHS, one test before and one test after the PMHS preparation; the results of these two experiments showed that head motion differences were substantial, especially after $140 \mathrm{~ms}$. However, such differences could also be attributed to varying test conditions slightly different impact speeds and different head restraint distances were used in these two experiments. Whichever way the visual targets are mounted, a video camera is used to track the targets. A typical acquisition rate of the camera in the analysed studies is $1 \mathrm{kHz}$. The accuracy of the displacement depends on the camera resolution and its position with respect to the subject. The camera position affects the field of view and its resolution affects the quality of the images acquired, and ultimately the accuracy of the captured vertebrae motion. The method of tracking of visual targets on the vertebrae is an absolute measurement method, i.e. this is directly measured with respect to a global reference frame. The intervertebral displacements are obtained from the video analysis, but this technique can have errors in the measurements. Lastly to mention, Ivancic et al. [41, 59] replaced the neck of the BioRID II with human cadaveric cervical spine and included artificial muscle force replications for stabilisation. Also here the intervertebral displacements are captured by video analysis. This method eliminates the anthropometric differences of the body and the head so that the cervical spine specimen is the solely difference. However, also the individual relationship between the subject's head weight and cervical spine characteristics are lost [25].

Another method for capturing intervertebral motion uses linear and angular acceleration sensors or angular rate sensors directly mounted on the anterior aspects of each cervical vertebral body with minimal damage [25]. These sensors are capable of a very high acquisition rate (e.g. $20 \mathrm{kHz}$ ) and are not limited by a field of view [25, 32]. This allows to test full body PMHS in realistic seating environments, e.g. Kang et al. [25] used an experimental seat that simulates yielding seat back, while Kang et al. [32] used actual production seats that have yielding seat back. The quality of the intervertebral motion can however be affected by the type of sensors used and their physical connection to the data acquisition unit. The velocity and displacement can be obtained by single and double integration respectively. However, this is a relative measurement method, i.e. this is not directly measured with respect to a global reference frame. Therefore this method requires that the initial configuration of the neck, vertebrae position and alignment, is measured before a dynamic test is performed [47]. This can be done for example with a X-Ray scan or with digitization using a coordinate measuring machine.

The third method of measuring intervertebral displacement relies on high-speed lateral X-Ray scans during a sled experiment. It is used on full body PMHS or human volunteers, it is the only technique capable to directly capture intervertebral displacement on volunteers. The acquisition rate is low: Deng [49] used 250 frames/s for her PMHS study, while the Japanese Automobile Research Institute (JARI) used a maximum acquisition rate 90 frames/s on volunteers to keep the radiation dose to the subjects low $[18,52-57]$. Two different doses and two different number of frames were used by JARI, (i) $0.016 \mathrm{mGy}$ per frame and up to 20 frames [52] or (ii) $0.073 \mathrm{mGy}$ per frame and up to 25 frames [55]. This X-Ray method does not require any instrumentation on the vertebrae and therefore does not affect the motion, but has the disadvantage that image analysis, i.e. the continuing tracking of vertebrae features, is a difficult process [47]. As a consequence PMHS studies used metal spheres [49] or metal screws [60] mounted on the vertebrae to provide better contrast in the captured images. In addition to the low acquisition rate of the X-Ray method, the relatively small field of view is another significant limitation to capture intervertebral displacement. The image area is limited by the image intensifier used, which converts X-Ray into visible light. The field of view for the Deng study is $25 \mathrm{x} 25 \mathrm{~cm}$ and for the JARI study $30 \times 30 \mathrm{~cm}$. Consequently, the X-Ray method has mainly been used with rigid seats (e.g. $[15,17,57,60,18,48,49,52-56])$ instead of yielding seats [25]. Moreover, it is difficult to visualize the entire cervical spine because of the human anatomy; the typical range for continuous analysis covers only $\mathrm{C} 2$ to $\mathrm{C} 6$ [47]. This is because $\mathrm{C} 1$, which does not have a vertebral body [61], may be obscured by the head and/or C2, while C7 and T1 may be obscured by the shoulder in the typical driving posture [62]. In some instances not even C6 can be tracked adequately, as White et al. [50] report for their study. Sato et al. [52] reported a resolution of 1280 x 1024 pixels and approximately 7.3 
pixels/mm for the JARI study, Gutsche et al. [60] reported approximately 2.7 pixels $/ \mathrm{mm}$ for their high speed X-Ray video.

The column in Table 1 'Negative Effect of Instrumentation' refers to how much the instrumentation affects the subject response during the rear-end impact experiment. Bertholon et al. [47] reported in their study that a weight of 50 grams is about $25 \%$ of the mass on one neck segment, which include the mass of a vertebra and surrounding soft tissue; this is slightly lower than the mass used by De Jager [63] in his mathematical model, who attributed a mass between 220 and 250 grams for each cervical neck segment. However, Bertholon et al. [47] also mention that the neck kinematics is more influenced by the head mass than the added mass to the vertebrae due to the instrumentation; the effective difference of added mass to vertebrae has not been investigated so far. Moreover, the attachment of any instrumentation to the vertebrae is an invasive method; the effect of such subject preparation to the intervertebral motion should be quantified, especially if the instrumentations require a physical connection to a data acquisition unit. Although the use of lateral X-Ray images offers a non-invasive method to capture intervertebral displacements, it is often preferred to attach small metal objects (metal balls or screws) to the vertebrae to enhance the visualisation of the X-Ray images [49, 60]. Although these additional objects do not require a physical connection to a data acquisition unit but are only for enhancing the visualisation, the effect of this invasive subject preparation to the intervertebral motion should be also quantified. The only volunteer study to capture the intervertebral displacements which used no instrumentation on the vertebrae to date was conducted by JARI [17, 18, 52-57]. Nevertheless, it should be noted that every rear-end impact experiment uses some type of instrumentation, especially for the head motion, also do the JARI studies.

Although a large number of experimental rear-end sled test studies can be found in the open domain, the number of cases which include the capture of intervertebral displacement is low. A summary of intervertebral displacement publications is given in the Appendix (Table A1) for ease of reference; it includes basic information for the experiments such as, subject type, number of subjects, intervertebral measuring method, acquisition rate and what intervertebral displacement data is published. The JARI studies [18, 52-57] are of special importance as they provide gender specific intervertebral displacement data on volunteers. During dynamic experiments, females showed larger segmental angular displacements than males [1, 3, 52]. However, higher injury risk for females cannot be generalised based on this larger displacement, because females have also larger segmental ROM limits compared to males [64].

All these findings underline the importance of intervertebral displacement for WAD studies.

\section{FINDINGS OF INTERVERTEBRAL DISPLACEMENT EXPERIMENTS}

The probably most commonly used whiplash injury criterion is NIC, the Neck Injury Criterion. The NIC hypothesis is based upon sudden spinal fluid pressure changes which may cause neural injury, but there may be other causes of injuries [27]. For example, the Intervertebral Neck Injury Criterion (IVNIC) hypotheses that intervertebral motion between two adjacent vertebrae beyond the physiological limit may injure spinal soft tissues during whiplash; this excessive intervertebral rotation is the injury hazard and causes high impact loads to ligamentous tissue, annulus fibers, and facet joints [26]. Clinical studies have documented such injuries in the spinal column [27].

The IV-NIC criterion was first introduced in 1999 by Panjabi et al. [27]. As shown in Eq. (1), the IVNIC is defined as the ratio of the intervertebral rotation under dynamic loading $\theta_{\text {dynamic }}$ to the physiological ROM $\theta_{\text {physiological. }}$ The IV-NIC is calculated separately for each intervertebral joint ' $i$ ' between the head and T1 and separately for flexion and extension between two adjacent vertebrae. Ivancic et al. [65] compared different injury criteria and concluded that IV-NIC is the only WAD criterion capable of identifying the location, bending mode (i.e. flexion/extension), severity and the time of exceeding intervertebral displacements. The injury criteria compared by Ivancic et al. are: Neck Injury Criterion (NIC), Normalized Neck Injury Criterion (Nij), Neck Protection Criterion (Nkm), Neck Displacement Criterion (NDC) and Inter- vertebral Neck Injury Criterion (IV-NIC). 


$$
\operatorname{IV-NIC}(t)=\frac{\theta_{\text {dynamic }, i}(t)}{\theta_{\text {physiological }, i}}
$$

An IV-NIC value above 1.0 indicates that the physiological ROM is exceeded, but at which point injury occurs is unclear; hence there is no agreed threshold value for injury. However, the IV-NIC may be able to indicate injuries such as ligament subfailure injury, annulus fibrosus tears, disc herniation, endplate and facet joint cartilage injury and synovial fold damage [26]. Several publications attempted to evaluate this criteria [26, 65-67]. For example, Ivancic et al. [68] suggests IV-NIC thresholds as follows; head/C1: 1.1; C3-C4: 1.1; C4-C5: 2.1; C5-C6: 1.5; C6-C7: 1.8; C7-T1: 2.9. Further evaluations of these thresholds would help to establish a standard on IV-NIC. However, no agreed values for physiological ROM between adjacent cervical vertebrae exist in the literature and females have also higher segmental ROM limits compared to males [64].

Panjabi et al. [26] conducted PMHS specimens experiments and calculated the IV-NIC at different impact speeds. Figure 1 shows a schematic view of the sled apparatus used; containing the acceleration generation system, impacting mass and breaking system. The Whole Cervical Spine (WCS) specimens were removed from all non-osteoligamentous soft tissues, however, Muscle Force Replications (MFR) were integrated to simulate passive muscle behaviour. The first thoracic T1 vertebra was rigidly attached to the sled. High-speed digital cameras recorded the motion of the vertebral visual markers at 500 frames/s. The physiological intervertebral flexibility parameters Neutral Zone (NZ) and Range of Motion (ROM) of the specimens were determined before and after the dynamic tests. NZ refers to the intervertebral displacement around the neutral posture with little soft tissue resistance. Extension rotations seem more hazardous than flexion rotations, therefore the peak extension rather than flexion IV-NIC are shown in Figure 2 for each intervertebral level at different T1 accelerations. Significant $(\mathrm{p}<0.05)$ increases in NZ, ROM or both before and after the dynamic tests at every intervertebral level are also shown in this figure. Such an increase indicates likelihood of injury to the WSC specimens. The highest IV-NIC peak in extension occurred for all impact accelerations at C7/T1.

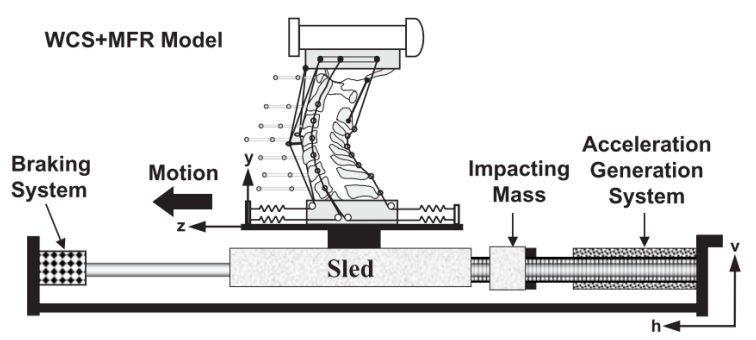

Figure 1: IV-NIC experiment performed by Panjabi et al. [26]. Human whole cervical spine (WCS) model with muscle force replication (MFR) for rear-end impact experiments.

In the studies of Panjabi et al. $[26,61]$ the highest risk for injury seems to be for intervertebral extension; flexion kinematic injuries are mentioned as 'unlikely' [61]. However, in the studies of Kang et al. [25, 32, 35] primary intervertebral flexion were observed; flexion kinematic injuries are mentioned as 'additional potential injury mechanism' [32]. However, these controversial conclusions may be because of the different experimental design. Panjabi et al. used cervical spine specimen which where accelerated only horizontally at T1, while Kang et al used full body PMHS seated in a yielding experimental or production seat; therefore vertical and rotational T1 motion is included. However, both studies agree that the excessive intervertebral rotations are a potential injury risk to soft-tissue. 


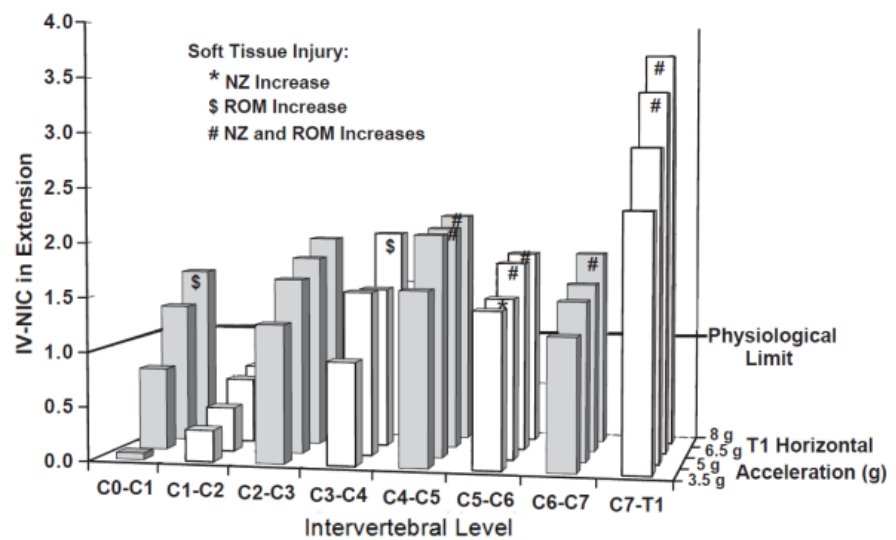

Figure 2: IV-NIC experiment performed by Panjabi et al. [26] (adapted figure). Average peak extension IV-NIC for each intervertebral level ( $\mathrm{C} 0-\mathrm{C} 1$ to $\mathrm{C} 7-\mathrm{T} 1)$ at 3.5, 5, 6.5, and $8 \mathrm{~g} \mathrm{~T} 1$ maximum horizontal accelerations. Intervertebral levels with potential injury risk due to NZ (normal zone), ROM (range of motion) or simultaneous $\mathrm{NZ}$ and ROM increase are indicated with $*$, $\$$ or \# respectively.

Facet joints are known to be a common source of neck pain; studies from Wayne State University [15, $48,51,69,70]$ have investigated kinematics and strain at the facet joints. Researchers from this group found that maximum facet stretch and strain occurred right before and at the head restraint contact. Clinical evidence for damage of facet joints have been reported by several researchers [29-32]. The detailed analysis of the location of the Instantaneous Axis of Rotation (IAR) between two adjacent vertebrae also showed an increasing risk for facet joint, because the IAR location is different between voluntary head motion and involuntary head motion during an impact impingement $[55,71,72]$. For normal circumstances, various researchers [73-75] used lateral X-Rays to investigate the IAR locations; the results from these non-impact-studies agree well with each other [63]. However, the JARI volunteer study [54-57] compared the IAR for the C5-C6 segment under crash conditions to voluntary head bending on the same volunteer. The JARI study noticed that there is an upward shift of the IAR (illustrated in Figure 3) between these two adjacent vertebrae; this results in an increasing risk for facet joint impingement and may cause whiplash injury $[7,55,71,72]$. Unfortunately, no other segments were analysed.

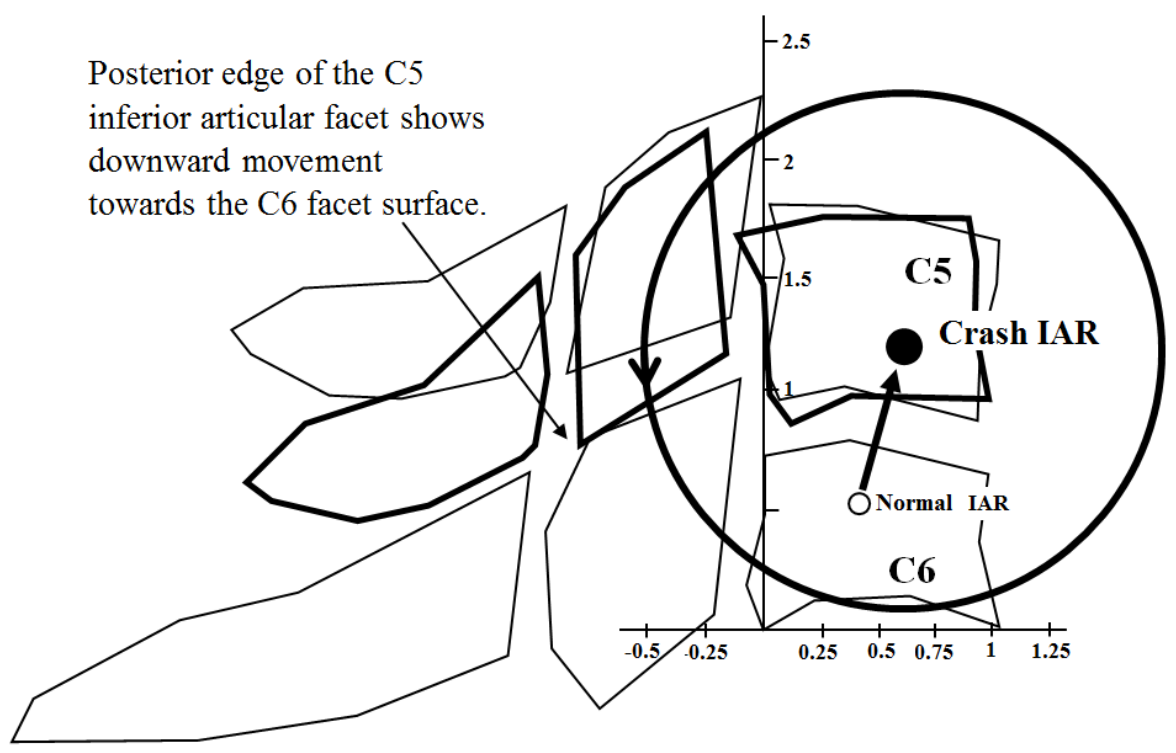

Figure 3: Upward shift of C5-C6 IAR under crash condition. Posterior edge of the C5 inferior articular facet shows downward movement toward the C6 facet surface, adapted from Ono et al. [56]. 
It is well known that during whiplash the spine forms a S-shape; consequently there is a point of which vertebrae levels above are in flexion, while vertebrae levels below are in extension. Panjabi et al. [61] named this point inflection point (IP) and conducted sled tests on cervical spine specimen. In their study the inflection point ranges for each specimen between $\mathrm{C} 2$ and $\mathrm{C} 4$; however, the inflection point does not change with the impact acceleration.

\section{COMPUTATIONAL MODELS WITH INTERVERTEBRAL MOTION VALIDATION}

Computer simulations have been used for more than 40 years to predict the behaviour of the humanbody in vehicle accidents. Several models have been designed to simulate such behaviour with the focus on rear-end impact accidents. However, computational models are in general only as representative as the experimental data used for their validation, and as good as the agreement of their simulations with such experimental data. Experimental data including intervertebral motion is rare for rear-end impacts (see Appendix Table A1); consequently, computational models which include validation of intervertebral displacement are also rare.

An important distinction between models is weather a model is calibrated for a certain response or if it is based tissue-level development. In a calibrated model, properties are adapted to satisfy experimental data, this could be the motion of intervertebral segments and/or the motion of the full neck during a rear-end impact, i.e. calibration. On contrary, a tissue-level based model is developed in detail with appropriate tissue levels and then tested against an experimental response, i.e. validation. A calibrated model is only valid for the range of conditions for which they were calibrated, the tissue-level based model leads to a predictive model, which should be validated for a range of different conditions to maximise its application range. Regardless of the model type, there are two approaches for the intervertebral calibration/validation of a computational model to experimental data: A model can be either verified on segmental level, i.e. for two adjacent vertebrae segments at a time, such as applying a torque or displacement on one segment and measuring a displacement or torque of the other segment respectively, or it can be verified by applying a whiplash penetration and monitoring the motion of the whole cervical spine and its segments continuously. By testing the whole cervical spine one can either compare the displacement over time continuously or compare the discreet peek rotational angles between the model response and experimental data.

Table 2 shows key information about some computational models which include continuous intervertebral displacement comparison during whiplash penetration. Computational models which are not compared for intervertebral motions, or are compared based on discreet peak rotational angles only, e.g. the state of the art GHBMC finite element model $[76,77]$, are not included in Table 2. The content of Table 2, the key information about some simulation models, is given below.

Yamazaki et al. (2000) used the mathematical head-and-neck model developed by De Jager [63] which was originally only validated for frontal and lateral impacts. The model consists of nine rigid bodies to represent the head $(\mathrm{C} 0)$, the seven cervical vertebrae (C1-C7) and the first thoracic vertebra (T1). Each vertebra is connected to its adjacent vertebrae by spring-damper elements to mimic all cervical soft tissues. These elements were adjusted by Yamazaki et al. to improve the response of the model for rear-end impact simulations. The experimental data for the validation was taken from the JARI study, but data from only one volunteer was used. The intervertebral rotations of the model agreed well with the volunteer data, however, intervertebral translation motions were not validated.

Stemper et al. [79] used their own rear-end experimental study results, using ligamentous PMHS cervical spine specimens [1,3], to validate a modified De Jager simulation model [63]. Intervertebral rotation corridors (originally not presented in publications $[1,3]$ of the sled-test study) were used for validation but only included rotations of C2-C3, C3-C4, C4-C5, C6-C7. However, Stemper et al. did not publish experimental intervertebral translations, and hence did not validate the computational model for such translations. Moreover, although experiments were conducted for three different impact velocities $(1.3,1.8$ and $2.6 \mathrm{~m} / \mathrm{s})$ and the computational model was validated for all of these, the 
published experimental results cover only the $2.6 \mathrm{~m} / \mathrm{s}$ impact velocity. Therefore, the available experimental data has limited use for other researchers to validate a computational model. Stemper et al. simulation results show acceptable agreement to the experimental data; however, it is questionable how biofidelic the experimental data is as PMHS cervical spine specimens have been used. In a follow-up study, Stemper et al. [80] investigated the effect of initial spinal curvature. They adjusted initial ligament lengths for the $\mathrm{C} 2-\mathrm{C} 3$ through $\mathrm{C} 6-\mathrm{C} 7$ spinal segment for each posture (lordosis, straight, kyphosis), hence each posture represents an individual with such a posture. Their research showed that an initial kyphotic cervical alignment has a greater elongation of the facet joints than those in lordotic cervical alignment.

Table 2: Summary of computational models which are validated for intervertebral motion.

\begin{tabular}{|c|c|c|c|c|}
\hline Publication & Model & Experimental Data & Limitation & Further Information \\
\hline$[78]$ & $\begin{array}{l}\text { Calibrated model. } \\
\text { Mathematical head-and- } \\
\text { neck model designed by } \\
\text { De Jager [63] with } \\
\text { modifications. }\end{array}$ & $\begin{array}{l}\text { Volunteer sled test } \\
\text { experiments performed by } \\
\text { JARI }[54,56,57] \text {, } \\
\text { optimization based on only } \\
\text { one volunteer. }\end{array}$ & $\begin{array}{l}\text { Only one volunteer, } \\
\text { only rotational } \\
\text { angles, no } \\
\text { intervertebral } \\
\text { translation }\end{array}$ & $\begin{array}{l}\text { Publication includes parameter } \\
\text { study to investigate the influence } \\
\text { of impact speed. }\end{array}$ \\
\hline [79] & $\begin{array}{l}\text { Calibrated model. } \\
\text { Mathematical head-and- } \\
\text { neck model designed by } \\
\text { De Jager [63] with } \\
\text { modifications. }\end{array}$ & $\begin{array}{l}\text { PMHS cervical spine } \\
\text { experiments conducted by } \\
\text { the same authors }[1,3]\end{array}$ & $\begin{array}{l}\text { Limitations due to } \\
\text { PMHS cervical } \\
\text { spine study, no } \\
\text { intervertebral } \\
\text { translation measured }\end{array}$ & $\begin{array}{l}\text { Validation corridors for the } \\
\text { experimental data were derived } \\
\text { from the same author group; } \\
\text { previously these corridors were } \\
\text { not published. }\end{array}$ \\
\hline$[81]$ & $\begin{array}{l}\text { Tissue-level based model. } \\
\text { Multi-Body Dynamics } \\
\text { head-and- neck model } \\
\text { designed by Van-Lopik. }\end{array}$ & $\begin{array}{l}\text { PMHS cervical spine } \\
\text { experiments conducted by } \\
\text { the Yale University School } \\
\text { of Medicine; all non- } \\
\text { osteoligamentous tissues } \\
\text { were removed before the } \\
\text { experiments. }\end{array}$ & $\begin{array}{l}\text { Limitations due to } \\
\text { PMHS cervical } \\
\text { spine study, no } \\
\text { intervertebral } \\
\text { translation. }\end{array}$ & $\begin{array}{l}\text { For the simulation all muscles } \\
\text { were set inactive (removed) to be } \\
\text { comparable to the experimental } \\
\text { data. Therefore, not even passive } \\
\text { muscle force is considered. }\end{array}$ \\
\hline$[82]$ & $\begin{array}{l}\text { Tissue-level based model. } \\
\text { Detailed 3D Finite } \\
\text { Element model }\end{array}$ & $\begin{array}{l}\text { PMHS sled test study by } \\
\text { Bertholon et al. [47] }\end{array}$ & $\begin{array}{l}\text { Experimental data } \\
\text { for intervertebral } \\
\text { rotations was only } \\
\text { available for thee } \\
\text { vertebrae. }\end{array}$ & $\begin{array}{l}\text { The follow-up study [83] } \\
\text { investigated intervertebral } \\
\text { rotations for different initial } \\
\text { cervical curvature. }\end{array}$ \\
\hline$[36]$ & $\begin{array}{l}\text { Tissue-level based model. } \\
\text { FE model developed by } \\
\text { Panzer (2006). }\end{array}$ & $\begin{array}{l}\text { Volunteer validation data by } \\
\text { Davidsson et al. [85] (no } \\
\text { intervertebral data) and } \\
\text { PMHS validation data by } \\
\text { Deng [49] (including } \\
\text { intervertebral data) }\end{array}$ & $\begin{array}{l}\text { PMHS study, } \\
\text { Intervertebral } \\
\text { displacement } \\
\text { inadequate. }\end{array}$ & $\begin{array}{l}\text { Upper vertebrae did not exhibit } \\
\text { enough relative flexion while the } \\
\text { lower vertebrae did not exhibit } \\
\text { enough relative extension. } \\
\text { Combination leads to good head } \\
\text { rotation. }\end{array}$ \\
\hline$[86]$ & $\begin{array}{l}\text { Calibrated model. } \\
\text { Mathematical head and } \\
\text { neck model similar to the } \\
\text { design of De Jager } \\
\text { (1996); simplification by } \\
\text { reducing intervertebral } \\
\text { translational movement. }\end{array}$ & $\begin{array}{c}\text { Same Experimental Data as } \\
\text { Van Lopik }\end{array}$ & $\begin{array}{l}\text { Same limitations as } \\
\text { Van Lopik }\end{array}$ & $\begin{array}{c}\text { Only revolute joints, } \\
\text { intervertebral translation not } \\
\text { possible. Intervertebral stiffness } \\
\text { and damping parameters derived } \\
\text { with optimization process. }\end{array}$ \\
\hline$[60]$ & $\begin{array}{l}\text { ATD model. } \\
\text { EvaRID: female virtual } \\
\text { version of the FE model } \\
\text { BioRID II }\end{array}$ & $\begin{array}{l}\text { Two female PMHS were } \\
\text { tested, intervertebral } \\
\text { displacement was captured } \\
\text { with X-Ray }\end{array}$ & $\begin{array}{l}\text { EvaRID, a virtual } \\
50^{\text {th }} \text { percentile } \\
\text { female BioRID-II }\end{array}$ & $\begin{array}{c}\text { Computational model of an } \\
\text { ATD. }\end{array}$ \\
\hline$[87]$ & $\begin{array}{l}\text { Tissue-level based model. } \\
\text { Head and neck finite } \\
\text { element model }\end{array}$ & $\begin{array}{l}\text { PMHS cervical spine } \\
\text { experiments conducted by } \\
\text { Stemper et al. [79] }\end{array}$ & $\begin{array}{l}\text { Limitations due to } \\
\text { PMHS cervical } \\
\text { spine study, no } \\
\text { intervertebral } \\
\text { translation measured }\end{array}$ & $\begin{array}{l}\text { Validation corridors for the } \\
\text { experimental data were taken } \\
\text { from Stemper et al. [79], but } \\
\text { these corridors are only available } \\
\text { for one impact speed }\end{array}$ \\
\hline$[88]$ & $\begin{array}{l}\text { Tissue-level based model. } \\
\text { Scaled THUMS model } \\
\text { (FE model) }\end{array}$ & $\begin{array}{l}\text { Volunteer sled test } \\
\text { experiments performed by } \\
\text { JARI, only } 2 \text { female } \\
\text { volunteers }[18]\end{array}$ & $\begin{array}{c}\text { Some responses } \\
\text { have low correlation }\end{array}$ & $\begin{array}{l}\text { Includes the whole spine } \\
\text { alignment and investigated the } \\
\text { effect of whole spine alignment } \\
\text { patterns. }\end{array}$ \\
\hline
\end{tabular}


Van Lopik (2004) developed a multi-body head-and-neck model with very detailed muscle and ligament locations in the neck, also including active muscle behaviour. The model was validated for frontal and lateral impacts against volunteer data (published by Naval Biodynamics Laboratory) as well as for rear-end impacts against the PMHS cervical spine study performed by the Yale University School of Medicine [28, 39, 40]. Since the Yale study had all non-osteoligamentous soft tissues removed before the experiments, Van Lopik disabled for his simulations all muscles to obtain a model to closely represent the experimental setup. The ligamentous computational spine model was validated on intervertebral rotational level against the ligamentous experimental data with reasonable success. Then, additional simulations including the muscles (with active muscle behaviour) were performed, but showed little differences to the previous simulation, indicating that muscles only have minor effect on the model developed by van Lopik. Lastly, simulations with and without gravity did also show small differences, indicating that also gravity has minor influence on the model.

Fréchéde et al. [82] developed a 3D finitel element model of the head and neck of a $50^{\text {th }}$ percentile male subject. The model was validated for different impact directions, and also included the validation against a rear-end sled experiment with intervertebral rotations published by Bertholon et al. [47]. Bertholon et al. measured the intervertebral rotations of three vertebrae (T1, C5 and C2) during PMHS experiments. The model developed by Fréchéde et al. showed similar intervertebral rotations to this experimental data. The follow-up study, Fréchéde et al. [83], investigated intervertebral rotations for different initial cervical curvature, i.e. lordotic, straight and kyphotic. It was concluded that although the global (gross) head motion remained similar, there are significvant changes in the intervertebral rotations. Consequently, the ligament elongations as well as forces and moments along the cervical spine were significantly different among the three curvatures. Similar conculsion was made by Pramudita et al. [89], who also investigeted the effect of initial cervical curvature with a finite element model. Their finitel elment model was modified using shape transformations to obtain different cervical curvatures, however, there model was not validated against intervertebral experimental data.

In 2008, Fice at al. [36] validated the detailed finite element (FE) head-and-neck model developed by Panzer [84] in 2006, which focused on accurate geometric and material representation at local tissue level. However, Fice at al. used two different rear-end impact studies for the validation: first, Davidsson et al. [85] who used volunteers without the capture of intervertebral displacement data, and second, Deng [49] who used full body PMHS including the captured of intervertebral displacement data. Results showed good agreement for the overall head motion using both validation studies, Davidsson and Deng. In most cases this would be accepted as a good model response. However, Fice et al. also compared the intervertebral rotations of the simulation model to experimental data of the Deng experiment and concluded that the upper cervical vertebra did not exhibit enough flexion, while the lower vertebra did not exhibit enough extension. The combination of these balancing inaccuracies resulted in a good overall head response but poor segmental response. This shows the importance of intervertebral displacement validation. To improve the model of Fice et al. more accurate tissue data studies may be helpful.

The study by Hoover et al. [86], focused primarily on intervertebral validation; their mathematical model used a lumped parameter approach similar to De Jager, but they used constant damping and stiffness values instead of non-linear functions as De Jager did. Hoover et al. model is twodimensional and uses rigid links between the IARs; intervertebral translation cannot be investigated with this approach. The constant damping and stiffness values were determined with an inverse analysis method which minimises the error of simulation compared to the experimental validation data, i.e. the global head displacement as well as the intervertebral rotation are minimized simultaneously. The experimental data was once again from the Yale University School of Medicine study [28, 39, 40]. This allows a direct comparison of the Hoover \& Meguid to the Van Lopik [81] model: Van Lopiks model, which is far more detailed, produced better results for the peak flexion in the upper cervical joints in the early trauma phase, but performed worse in the peak extension of the joint C1-C2 in the later trauma phase. However, the Yale University School of Medicine study hypothesize that the lower cervical spine is at higher risk. For this region none of the two 
computational models agree sufficiently, but the model by Van Lopik has superior results. The reason is probably because the model by Van Lopik allows intervertebral translations. A graphical comparison of experimental results to both of these two computational models can be found in the publication by Hoover et al. [86].

Gutsche et al. [60] validated the virtual crash test dummy EvaRID, a scaled down version of the existing BioRID II to represent the average female occupant [90], for intervertebral rotations. They used two female PMHS to conduct eight sled test experiments while the intervertebral motion was captured with high-speed lateral X-Ray images. The EvaRID model represents an ATD and not a human subject, therefore has limited response due to its design. The virtual model responses showed good correlation to the PMHS experiments for the global kinematics of head and upper body; however, EvaRID showed higher bending of the lower neck than the PMHS. There is also a brief comparison to the virtual BioRID II given, as not unexpected its behaviour is similar to EvaRID. A comparison to a physical BioRID II is not given.

Zhang et al. [87] used for the validation of their finite element model the corridors provided by Stemper et al. [79]. However, Stemper et al. provided only limited data which is suitable for validation, i.e. only for one impact speed although tests with other impacts speeds have been performed. However, the model of Zhang et al. showed reasonable agreement with the available validation data. Additional segmental validation would be beneficial.

Sato et al. [88] analyzed the effect of whole spine alignment patterns on the neck responses in rear-end impacts for both genders. The FE model THUMS AF05 $\left(5^{\text {th }}\right.$ percentile female) was scaled up to represent the average female occupant and material properties were modified to increase the biofidelic response. The simulation result was validated against the JARI study [18], which included two female and four male volunteers in a rear-end sled experiment while their vertebral motion was captured with lateral X-Ray images. Some intervertebral computational responses showed low correlation with the experimental data, but in general most simulation results were in a good agreement. To compare the gender behavior, this model was adjusted to two different spinal alignment patterns: one with the typical female and one with the typical male spinal alignment pattern. The simulation with typical female spine alignment showed in the cervical spine larger intervertebral angular displacements compared to the simulation with typical male spinal alignment, although the male T1 angular displacement was even bigger than the female $\mathrm{T} 1$ angular displacement.

\section{CONCLUSIONS}

A comprehensive review regarding the importance of intervertebral displacements for whiplash investigations has been presented. The methodology, benefits and limitations of different existing intervertebral displacement studies have been analysed and compared, and the related contributions to knowledge of these studies have been summarized.

Rotational intervertebral displacements are an important measure in whiplash trauma investigations. Analyses of various techniques and their respective limitations in capturing the intervertebral displacement data, showed that it is difficult to capture intervertebral displacement in rear-end experiments, and every method has its own benefits and drawbacks. In general there have been three different methods used in the past, tracking of visual targets attached to the vertebrae, angular sensors which are attached to the vertebrae and lateral X-Ray scans during the impact. The last method is the only method which allows the use of volunteers, but the ethical issues and the radiation safety hazard to the volunteers cannot be neglected.

Sled test experiments conducted in the last two decades showed that intervertebral rotations can exceed physiological limits during whiplash trauma. This has been shown in PMHS [1, 25, 28, 48, 51, 61] but also in volunteers [52]. These excessive rotations have the potential for soft-tissue injury, especially since an increase in the Neutral Zone and in the Range of Motion compared before and after the experiment have been observed in PHMS studies. There have been also clinical observations reported 
which support the hypothesis of soft tissue injury. Angular intervertebral displacements can be evaluated using the Intervertebral Neck Injury Criterion, but no agreed thresholds are available in the literature. Ivancic et al. [68] proposed thresholds for the IV-NIC, however, further experimental study is required.

Computational models are frequently used for whiplash investigations, and with each generation more anatomical details and better accuracy are incorporated. However, future models should be also verified for intervertebral rotations. It has been also highlighted that the head kinematics can have very good agreement to experimental data, although the neck segmental kinematics agrees poorly, e.g. the model developed by Fice et al. [36]. Therefore, results of computational simulations, which use a model which has not been validated for intervertebral displacements during crash conditions, should be used with caution, especially if it is intended to investigate segmental neck or tissue deformation. An important distinction between models is weather a model is calibrated for a certain response or if it is tissue-level based. A calibrated model can better represent the intervertebral rotations during whiplash penetration than a model which is developed from tissue-level, but a calibrated model is also only valid for the range of conditions for which they were calibrated. For a tissue-level based model, the intervertebral rotations during whiplash penetration are not as accurate despite the fact that the most accurate geometric and material representation are used. Yet, the model can be used for a wider range of conditions.

There is a limited number of publications for experimental rear-end sled tests which include intervertebral motion data. Unfortunately such publications include intervertebral motion data relevant only for the publications purpose. Therefore, these data-sets are often incomplete and cannot be used for validation of a computational model. Additionally, intervertebral motion data is usually of mixed gender, but it has been revealed that females have shown higher segmental angular displacements than males. Further sled test experiments which include intervertebral motion data are essential for whiplash investigations and should be published gender specific.

\section{REFERENCES}

1. Stemper, B. D., Yoganandan, N., \& Pintar, F. A. (2003). Gender dependent cervical spine segmental kinematics during whiplash. Journal of Biomechanics, 36(9), 1281-1289. doi:10.1016/S0021-9290(03)00159-3

2. NHS. (2014). Whiplash. NHS choices. Retrieved July 30, 2016, from http://www.nhs.uk/conditions/whiplash/Pages/Introduction.aspx

3. Stemper, B. D., Yoganandan, N., \& Pintar, F. A. (2004). Gender- and region-dependent local facet joint kinematics in rear impact: implications in whiplash injury. Spine, 29(16), 1764-1771. doi:10.1097/01.BRS.0000134563.10718.A7

4. Carlsson, A., Linder, A., Davidsson, J., Hell, W., Schick, S., \& Svensson, M. (2011). Dynamic kinematic responses of female volunteers in rear impacts and comparison to previous male volunteer tests. Traffic Injury Prevention, 12(4), 347-57. doi:10.1080/15389588.2011.585408

5. Svensson, M. Y., Boström, O., Davidsson, J., Hansson, H.-A., Haland, Y., Lövsund, P., ... Säljö, A. (2000). Neck injuries in car collisions--a review covering a possible injury mechanism and the development of a new rear-impact dummy. Accident Analysis \& Prevention, 32(2), 167-175. doi:10.1016/S0001-4575(99)00080-9

6. Carlsson, A. (2012). Addressing Female Whiplash Injury Protection - A Step Towards 50th Percentile Female Rear Impact Occupant Models. PhD Thesis - Chalmers University of Technology, Sweden.

7. Bogduk, N., \& Yoganandan, N. (2001). Biomechanics of the cervical spine Part 3: Minor injuries. Clinical Biomechanics, 16(4), 267-275. doi:10.1016/S0268-0033(01)00003-1

8. Svensson, M. (2005). Neck injuries in car collisions - Injury mechanisms. Proceedings Injury in Low Velocity Collision Conference, 1-11.

9. EURO NCAP. (2009). Whiplash. The Rating Explained - Whiplash . Retrieved July 27, 2016, from http://www.euroncap.com/en/vehicle-safety/the-ratings-explained/adult-occupant-protection/whiplash/ 
10. NHTSA. (2015). Traffic Safety Facts 2014 - A Compilation of Motor Vehicle Crash Data from the Fatality Analysis Reporting System and the General Estimates System. National Highway Traffic Safety Administration - U.S. Department of Transportation.

11. Watanabe, Y., Ichikawa, H., Kayama, O., Ono, K., Kaneoka, K., \& Inami, S. (2000). Influence of seat characteristics on occupant motion in low-speed rear impacts. Accident Analysis and Prevention, 32(2), 243-250. doi:10.1016/S0001-4575(99)00082-2

12. Eis, V., Sferco, R., \& Fay, P. (2005). Detailed Analysis of the Characteristics of European Rear Impacts. 19th International ESV Conference, 1-9.

13. Favarò, F. M., Nader, N., Eurich, S. O., Tripp, M., \& Varadaraju, N. (2017). Examining accident reports involving autonomous vehicles in California. PloS one, 12(9), e0184952. doi:10.1371/journal.pone.0184952

14. O'Neill, B. (2000). Head restraints - The neglected countermeasure. Accident Analysis and Prevention, 32(2), 143150. doi:10.1016/S0001-4575(99)00057-3

15. Luan, F., Yang, K. H., Deng, B., Begeman, P. C., Tashman, S., \& King, A. I. (2000). Qualitative analysis of neck kinematics during low-speed rear-end impact. Clinical Biomechanics, 15(9), 649-657.

16. McConnell, W. E., Howard, R. P., Guzman, H. M., Bomar, J. B., Raddin, J. H., Benedict, J. V, ... Hatsell, C. P. (1993). Analysis of Human Test Subject Kinematic Responses to Low Velocity Rear End Impacts. SAE Technical Paper, No. 930889. doi:10.4271/930889

17. Matsushita, T., Sato, T. B., Hirabayashi, K., Fujimura, S., Asazuma, T., \& Takatori, T. (1994). X-Ray Study of the Human Neck Motion Due to Head Inertia Loading. Proceedings of 38th Stapp Car Crash Conference, LauderdaleFlorida (USA), 55-64. doi:10.4271/942208

18. Ono, K., Ejima, S., Suzuki, Y., Kaneoka, K., Fukushima, M., \& Ujihashi, S. (2006). Prediction of Neck Injury Risk Based on the Analysis of Localized Cervical Vertebral Motion of Human Volunteers During Low-Speed Rear Impacts. IRCOBI Conference Proceedings, 103-113.

19. Chirwa, E. C., \& Wang, W. (1997). Mechanics of a mechanically triggered airbag head restraint system for occupant protection in rear end impact. International Journal of Crashworthiness, 2(2), 165-190. doi:10.1533/cras.1997.0042

20. Acar, M., \& Bewsher, S. R. (2016). Design concepts for an integrated whiplash mitigating head restraint and seat. International Journal of Crashworthiness, 21(1), 79-88. doi:10.1080/13588265.2015.1116427

21. Schmitt, K. U., Beyeler, F., Muser, M., \& Niederer, P. (2004). A visco-elastic foam as head restraint material Experiments and numerical simulations using a biorid model. International Journal of Crashworthiness, 9(4), 341348. doi:10.1533/ijcr.2004.0294

22. Latchford, J., \& Chirwa, E. C. (2000). Airbag head restraint system. Proceedings of the Institution of Mechanical Engineers, Part D: Journal of Automobile Engineering, 214(3), 229-241. doi:10.1243/0954407001527385

23. Latchford, J., Chirwa, E. C., Chen, T., \& Mao, M. (2005). The relationship of seat backrest angle and neck injury in low-velocity rear impacts. Proceedings of the Institution of Mechanical Engineers, Part D: Journal of Automobile Engineering, 219(11), 1293-1302. doi:10.1243/095440705X34946

24. Himmetoglu, S. (2008). Car Seat Design And Human-Body Modelling For Rear Impact Whiplash Mitigation. PhD Thesis - Loughborough University, United Kingdom.

25. Kang, Y.-S., Moorhouse, K., Herriott, R., \& Bolte, J. H. (2013). Comparison of cervical vertebrae rotations for PMHS and BioRID II in rear impacts. Traffic Injury Prevention, 14, 136-47. doi:10.1080/15389588.2013.799280

26. Panjabi, M. M., Ito, S., Ivancic, P. C., \& Rubin, W. (2005). Evaluation of the intervertebral neck injury criterion using simulated rear impacts. Journal of Biomechanics, 38(8), 1694-1701. doi:10.1016/j.jbiomech.2004.07.015

27. Panjabi, M. M., Wang, J., \& Delson, N. (1999). Neck Injury Criterion Based on Intervertebral Motions and its Evaluation using an Instrumented Neck Dummy. IRCOBI Conference Proceedings, 179-190.

28. Grauer, J. N., Panjabi, M. M., Cholewicki, J., Nibu, K., \& Dvorak, J. (1997). Whiplash Produces an S-Shaped Curvature of the Neck With Hyperextension at Lower Levels. Spine, 22(21), 2489-2494.

29. Lord, S. M., Barnsley, L., Wallis, B. J., \& Bogduk, N. (1996). Chronic Cervical Zygapophysial Joint Pain After Whiplash. Spine, 21(15), 1737-1744. doi:10.1097/00007632-199608010-00005 
30. Lord, S. M., Barnsley, L., Wallis, B. J., McDonald, G. J., \& Bogduk, N. (1996). Percutaneous radio-frequency neurotomy for chronic cervical zygapophyseal-joint pain. The New England journal of medicine, 335(23), 17211726. doi:10.1056/NEJM199612053352302

31. Barnsley, L., Lord, S. M., Wallis, B. J., \& Bogduk, N. (1995). The Prevalence of Chronic Cervical Zygapophysial Joint Pain After Whiplash. Spine, 20(1), 20-26. doi:10.1097/00007632-199608010-00005

32. Kang, Y.-S., Moorhouse, K., Herriott, R., \& Bolte, J. H. (2014). Head and Cervical Spine Responses of Post Mortem Human Subjects in Moderate Speed Rear Impacts. IRCOBI Conference Proceedings, 268-285.

33. Pettersson, K. M., Hildingsson, Christer MD, P., Toolanen, Göran MD, PhD Fagerlund, Markku MD, P., \& Björnebrink, J. M. (1997). Disc Pathology After Whiplash Injury: A Prospective Magnetic Resonance Imaging and Clinical Investigation. Spine, 22(3), 283-287.

34. Uhrenholt, L., Grunnet-Nilsson, N., \& Hartvigsen, J. (2002). Cervical spine lesions after road traffic accidents: a systematic review. Spine, 27(17), 1934-41; discussion 1940. doi:10.1097/01.BRS.0000025477.02551.CD

35. Kang, Y.-S., Moorhouse, K., Icke, K., Stricklin, J., Herriott, R., \& Bolte IV, J. (2015). Rear Impact Head and Cervical Spine Kinematics of BioRID II and PMHS in Production Seats. IRCOBI Conference Proceedings, 246260 .

36. Fice, J. B., Cronin, D. S., \& Panzer, M. B. (2008). Investigation of Facet Joint Response under Rear Impact Conditions using FE Model of the Cervical Spine. Proceedings of the 21st International Technical Conference on the Enhanced Safety of Vehicles (ESV).

37. Stemper, B. D., Yoganandan, N., Rao, R. D., \& Pintar, F. A. (2005). Influence of thoracic ramping on whiplash kinematics. Clinical Biomechanics, 20(10), 1019-1028. doi:10.1016/j.clinbiomech.2005.06.011

38. Panjabi, M. M., Miura, T., Cripton, P. A., Wang, J.-L., Nain, A. S., \& DuBois, C. (2001). Development of a system for in vitro neck muscle force replication in whole cervical spine experiments. Spine, 26(20), 2214-2219. doi:10.1097/00007632-200110150-00012

39. Panjabi, M. M., Nibu, K., \& Cholewicki, J. (1998). Whiplash injuries and the potential for mechanical instability. European Spine Journal, 7(6), 484-492. doi:10.1007/s005860050112

40. Panjabi, M. M., Cholewicki, J., Nibu, K., Grauer, J. N., Babat, L. B., \& Dvorak, J. (1998). Mechanism of whiplash injury. Clinical Biomechanics, 13(4-5), 239-249. doi:10.1016/S0268-0033(98)00033-3

41. Ivancic, P. C., \& Xiao, M. (2011). Understanding whiplash injury and prevention mechanisms using a human model of the neck. Accident Analysis \& Prevention, 43(4), 1392-1399. doi:10.1016/j.aap.2011.02.014

42. Ivancic, P. C., Sha, D., Lawrence, B. D., \& Mo, F. (2010). Effect of Active Head Restraint on Residual Neck Instability due to Rear Impact. Spine, 35(23), 2071-2078. doi:10.1097/BRS.0b013e3181d04d2b

43. Tencer, A. F., Mirza, S., \& Huber, P. (2004). A Comparison of Injury Criteria Used in Evaluating Seats for Whiplash Protection. Traffic Injury Prevention, 5(1), 56-66. doi:10.1080/15389580490269209

44. Ivancic, P. C., Pearson, A. M., Panjabi, M. M., \& Ito, S. (2004). Injury of the anterior longitudinal ligament during whiplash simulation. European Spine Journal, 13(1), 61-68. doi:10.1007/s00586-003-0590-3

45. Geigl, B. C. (1997). Bewegung der Halswirbeläule beim Heckaufprall. PhD Thesis - Graz University of Technology, Austria, in German.

46. Geigl, B. C., Steffan, H., Leinzinger, P., Roll, P., Mühlbauer, M., \& Bauer, G. (1994). The Movement of Head and Cervical Spine During Rearend Impact. IRCOBI Conference Proceedings, 127-138.

47. Bertholon, N., Robin, S., Le Coz, J.-Y., Potier, P., Lassau, J.-P., \& Skalli, W. (2000). Human Head and Cervical Spine Behaviour During Low-Speed Rear-End Impacts: PMHS Sled Tests with a Rigid Seat. IRCOBI Conference Proceedings, 265-277. doi:10.1017/CBO9781107415324.004

48. Deng, B., Begeman, P. C., Yang, K. H., Tashman, S., \& King, A. I. (2000). Kinematics of Human Cadaver Cervical Spine During Low Speed Rear-End Impacts. Stapp Car Crash Journal, 44, 171-188.

49. Deng, B. (1999). Kinematics of human cadaver cervical spine during low speed rear-end impacts. PhD Thesis Wayne State University, USA. 
50. White, N. a, Begeman, P. C., Hardy, W. N., Yang, K. H., Ono, K., Sato, F., ... Bey, M. J. (2009). Investigation of Upper Body and Cervical Spine Kinematics of Post Mortem Human Subjects (PMHS ) during Low-Speed, RearEnd Impacts. SAE Technical Paper, No. 2009-0. doi:10.4271/2009-01-0387

51. Sundararajan, S., Priya, P., Demetropoulos, C. K., Tashman, S., Begeman, P. C., Yang, K. H., \& King, A. I. (2004) Effect of Head-Neck Position on Cervical Facet Stretch of Post Mortem Human Subjects during Low Speed Rear End Impacts. Stapp Car Crash Conference, 48, 331-372.

52. Sato, F., Nakajima, T., Ono, K., Svensson, M., \& Kaneoka, K. (2015). Characteristics of Dynamic Cervical Vertebral Kinematics for Female and Male Volunteers in Low speed Rear Impact, based on Quasi-static Neck Kinematics. IRCOBI Conference Proceedings, 261-277.

53. Sato, F., Nakajima, T., Ono, K., \& Svensson, M. (2014). Dynamic Cervical Vertebral Motion of Female and Male Volunteers and Analysis of its Interaction with Head/Neck/Torso Behavior during Low-Speed Rear Impact. IRCOBI Conference Proceedings, 227-249.

54. Ono, K., Kaneoka, K., Wittek, A., \& Kajzer, J. (1997). Cervical injury mechanism based on the analysis of human cervical vertebral motion and head-neck-torso kinematics during low speed rear impacts. Proceedings of 41st Stapp Car Crash Journal, Lake Buena Vista - Florida (USA), 339-356. doi:10.4271/973340

55. Kaneoka, K., Ono, K., Inami, S., \& Hayashi, K. (1999). Motion Analysis of Cervical Vertebrae During Whiplash Loading. Spine, 24(8), 763-770.

56. Ono, K., Kaneoka, K., \& Inami, S. (1998). Influence of seat properties on human vertebral motion and head/neck/torso kinematics during rear-end impacts. IRCOBI Conference Proceedings, 303-318.

57. Ono, K., \& Kaneoka, K. (1999). Motion Analysis of Human Cervical Vertebrae During Low-Speed Rear Impacts by the Simulated Sled. Journal of Crash Prevention and Injury Control, 1(2), 87-99. doi:10.1080/10286589908915746

58. Ito, S., Ivancic, P. C., Panjabi, M. M., \& Cunningham, B. W. (2004). Soft tissue injury threshold during simulated whiplash: a biomechanical investigation. Spine, 29(9), 979-87. doi:10.1097/00007632-200405010-00006

59. Ivancic, P. C., Sha, D., \& Panjabi, M. M. (2009). Whiplash injury prevention with active head restraint. Clinical Biomechanics, 24(9), 699-707. doi:10.1016/j.clinbiomech.2009.06.011

60. Gutsche, A. J., Tomasch, E., Darok, M., Sinz, W., Ciglaric, I., Ravnik, D., \& Steffan, H. (2014). Comparison of the cervical spine bony kinematics for female PMHS with the virtual EvaRID dummy under whiplash loading. IRCOBI Conference Proceedings, 528-541.

61. Panjabi, M. M., Pearson, A. M., Ito, S., Ivancic, P. C., \& Wang, J.-L. (2004). Cervical spine curvature during simulated whiplash. Clinical Biomechanics, 19(1), 1-9. doi:10.1016/j.clinbiomech.2003.09.006

62. Klinich, K. D., Ebert, S. M., Van Ee, C. A., Flannagan, C. A. C., Prasad, M., Reed, M. P., \& Schneider, L. W. (2004). Cervical Spine Geometry in the Automotive Seated Posture: Variations with Age, Stature, and Gender. Stapp Car Crash Journal, 48, 301-330.

63. de Jager, M. (1996). Mathematical Head-Neck Models for Acceleration Impacts. PhD Thesis - Eindhoven University of Technology, Netherlands. doi:10.6100/IR460661

64. Liu, B., Wu, B., Van Hoof, T., Okito, J.-P. K., Liu, Z., \& Zeng, Z. (2015). Are the standard parameters of cervical spine alignment and range of motion related to age, sex, and cervical disc degeneration? Journal of Neurosurgery: Spine, 23(3), 274-279. doi:10.3171/2015.1.SPINE14489

65. Ivancic, P. C., \& Sha, D. (2010). Comparison of the whiplash injury criteria. Accident Analysis \& Prevention, 42(1), 56-63. doi:10.1016/j.aap.2009.07.001

66. Panjabi, M. M., Ivancic, P. C., Tominaga, Y., \& Wang, J.-L. (2005). Intervertebral Neck Injury Criterion for Prediction of Multiplanar Cervical Spine Injury Due to Side Impacts. Traffic Injury Prevention, 6(4), 387-397. doi:10.1080/15389580500257100

67. Ivancic, P. C., Panjabi, M. M., Tominaga, Y., \& Malcolmson, G. F. (2006). Predicting multiplanar cervical spine injury due to head-turned rear impacts using IV-NIC. Traffic Injury Pevention, 7(3), 264-275. doi:10.1080/15389580500488499

68. Ivancic, P. C., Panjabi, M. M., Tominaga, Y., \& Malcolmson, G. F. (2006). Predicting multiplanar cervical spine injury due to head-turned rear impacts using IV-NIC. Traffic Injury Prevention, 7(3), 264-275. 
doi:10.1080/15389580500488499

69. Yoganandan, N., Pintar, F. a, \& Klienberger, M. (1998). Cervical Spine Vertebral and Facet Joint Kinematics Under Whiplash. Journal of Biomechanical Engineering, 120(2), 305-307. doi:10.1115/1.2798318

70. Yoganandan, N., Pintar, F. A., \& Cusick, J. F. (2002). Biomechanical analyses of whiplash injuries using an experimental model. Accident Analysis \& Prevention, 34(5), 663-671. doi:10.1016/S0001-4575(01)00066-5

71. Ono, K., Inami, S., Kaneoka, K., Gotou, T., Kisanuki, Y., Sakuma, S., \& Miki, K. (1999). Relationship between Localized Spine Deformation and Cervical Vertebral Motions for Low Speed Rear Impacts Using Human Volunteers. IRCOBI Conference Proceedings, 149-164.

72. Mordaka, J. K. (2004). Finite Element Analysis of Whiplash Injury for Women. PhD Thesis - The Nottingham Trent University, United Kingdom.

73. Mameren, van H., Sanches, H., Beursgens, J., \& Drukker, J. (1992). Cervical Spine Motion in the Sagittal Plane II: Position of Segmental Averaged Instantaneous Centers of Rotation - A Cineradiographic Study. Spine, 17(5), 467474. doi:10.1097/00007632-199205000-00001

74. Dvorak, J., Panjabi, M. M., Novotny, J., \& Antinnes, J. (1991). In vivo flexion/extension of the normal cervical spine. Journal of Orthopaedic Research, 9(6), 824-834.

75. Amevo, B., Worth, D., \& Bogduk, N. (1991). Instantaneous axes of rotation of the typical cervical motion segments: A study in normal volunteers. Clinical Biomechanics, 6(2), 111-117. doi:10.1016/0268-0033(91)90008-E

76. White, N. A., Moreno, D. P., Gayzik, F. S., \& Stitzel, J. D. (2015). Cross-sectional neck response of a total human body FE model during simulated frontal and side automobile impacts. Computer Methods in Biomechanics and Biomedical Engineering. Taylor \& Francis. doi:10.1080/10255842.2013.792918

77. Barker, J. B., Cronin, D. S., \& Nightingale, R. W. (2017). Lower Cervical Spine Motion Segment Computational Model Validation: Kinematic and Kinetic Response for Quasi-Static and Dynamic Loading. Journal of Biomechanical Engineering, 139(6), 061009. doi:10.1115/1.4036464

78. Yamazaki, K., Ono, K., \& Kaneoka, K. (2000). A Simulation Analysis of Human Cervical Spine Motion During Low Speed Rear-End Impacts. SAE Technical Paper, No. 2000-0. doi:10.4271/2000-01-0154

79. Stemper, B. D., Yoganandan, N., \& Pintar, F. A. (2004). Validation of a head-neck computer model for whiplash simulation. Medical \& Biological Engineering \& Computing, 42(3), 333-338. doi:10.1007/BF02344708

80. Stemper, B. D., Yoganandan, N., \& Pintar, F. A. (2005). Effects of abnormal posture on capsular ligament elongations in a computational model subjected to whiplash loading. Journal of Biomechanics, 38(6), 1313-1323. doi:10.1016/j.jbiomech.2004.06.013

81. van Lopik, D. (2004). A Computational Model of the Human Head and Cervical Spine for Dynamic Impact Simulation. PhD Thesis - Loughborough University, United Kingdom.

82. Fréchède, B., Bertholon, N., Le Coz, J.-Y., Lavaste, F., \& Skalli, W. (2005). Finite element model of the human neck during omni-directional impacts. Part I. Kinematics and injury. Revue européenne des éléments finis, 14(4-5), 463-485. doi:10.3166/reef.14.463-485

83. Fréchède, B., Bertholon, N., Saillant, G., Lavaste, F., \& Skalli, W. (2006). Finite element model of the human neck during omni-directional impacts. Part II: relation between cervical curvature and risk of injury. Computer Methods in Biomechanics and Biomedical Engineering, 9(6), 379-386. doi:10.1080/10255840600980940

84. Panzer, M. B. (2006). Numerical Modelling of the Human Cervical Spine in Frontal Impact. PhD Thesis - Waterloo University, Canada.

85. Davidsson, J., Deutscher, C., Hell, W., Lövsund, P., \& Svensson, M. (2001). Human Volunteer Kinematics in RearEnd Sled Collisions. Journal of Crash Prevention and Injury Control, 2(4), 319-333. doi:10.1080/10286580008902576

86. Hoover, J., \& Meguid, S. A. (2015). Analytical viscoelastic modelling of whiplash using lumped-parameter approach. International Journal of Mechanics and Materials in Design, 11(2), 125-137. doi:10.1007/s10999-0159306-1

87. Zhang, Q. H., Teo, E. C., \& Ng, H. W. (2015). Development and Validation of A C0 - C7 FE Complex for 
Biomechanical Study. Journal of Biomechanical Engineering, 127(October 2005), 729-735. doi:10.1115/1.1992527

88. Sato, F., Odani, M., Miyazaki, Y., Yamazaki, K., Osth, J., \& Svensson, M. (2017). Effects of whole spine alignment patterns on neck responses in rear end impact. Traffic Injury Prevention, 18(2), 199-206.

doi:10.1080/15389588.2016.1227072

89. Pramudita, J. A., Kikuchi, S., Minato, I., \& Tanabe, Y. (2017). Effect of cervical spine alignment on neck injury risk during rear-end impact - numerical study using neck finite element model. International Journal of Crashworthiness, 22(4), 453-466. doi:10.1080/13588265.2017.1278638

90. Linder, A., Schick, S., Hell, W., Svensson, M., Carlsson, A., Lemmen, P., ... Tomasch, E. (2013). ADSEAT Adaptive seat to reduce neck injuries for female and male occupants. Accident Analysis and Prevention, 60, 334343. doi:10.1016/j.aap.2013.02.043

91. Tencer, a F., Huber, P., \& Mirza, S. K. (2003). A comparison of biomechanical mechanisms of whiplash injury from rear impacts. Annual Proceedings / Association for the Advancement of Automotive Medicine., 47, 383-398.

92. Ivancic, P. C., Panjabi, M. M., Ito, S., Cripton, P. a., \& Wang, J. L. (2005). Biofidelic whole cervical spine model with muscle force replication for whiplash simulation. European Spine Journal, 14(4), 346-355.

doi:10.1007/s00586-004-0758-5 


\section{APPENDIX}

Table A1: Summary of experimental intervertebral displacement studies.

\begin{tabular}{|c|c|c|c|c|c|c|c|c|c|c|c|}
\hline $\begin{array}{c}\text { Year and } \\
\text { Publication }\end{array}$ & $\begin{array}{l}\text { Subject } \\
\text { Type; } \\
\text { Number of } \\
\text { Subjects }\end{array}$ & $\begin{array}{l}\text { Measuring } \\
\text { Method; } \\
\text { Acquisition } \\
\quad \text { Rate }\end{array}$ & $\begin{array}{l}\text { Additional Information } \\
\text { and Limitations }\end{array}$ & $\begin{array}{c}\text { Head } \\
\text { Restraint }\end{array}$ & 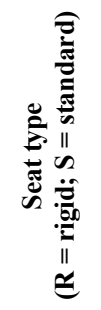 & 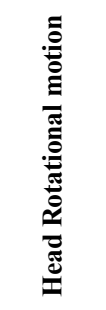 & 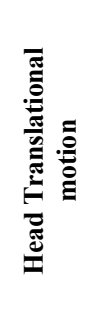 & 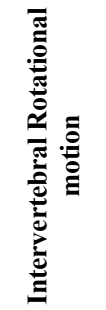 & 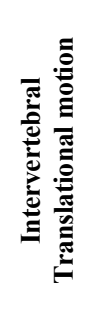 & 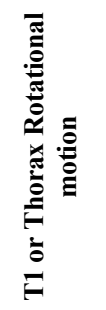 & 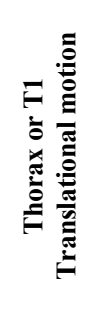 \\
\hline $\begin{array}{l}\mathbf{1 9 9 4} \\
{[17]}\end{array}$ & $\begin{array}{l}\text { Volunteer; } \\
22 \text { males } \\
\text { and } 4 \\
\text { females } \\
\text { (different } \\
\text { impact } \\
\text { directions) }\end{array}$ & $\begin{array}{c}\text { X-Ray; } \\
90 \mathrm{~Hz}\end{array}$ & $\begin{array}{c}\text { No time dependent } \\
\text { intervertebral motion } \\
\text { published although tracked; } \\
\text { Presumable small field of } \\
\text { view due to image } \\
\text { intensifier (not specified). }\end{array}$ & Yes & S & No & $\begin{array}{l}\text { Partly } \\
\text { Hori- } \\
\text { zontal } \\
\text { Yes; } \\
\text { Verti- } \\
\text { cal No }\end{array}$ & $\begin{array}{l}\text { No } \\
\text { Al- } \\
\text { though } \\
\text { tracked }\end{array}$ & No & No & No \\
\hline $\begin{array}{c}1997 \\
{[45,46]}\end{array}$ & $\begin{array}{l}\text { Full body } \\
\text { PMHS; } \\
4 \text { males and } \\
2 \text { females }\end{array}$ & $\begin{array}{l}\text { visual targets } \\
\text { on two } \\
\text { vertebrae and } \\
\text { high speed } \\
\text { video camera; } \\
1000 \mathrm{~Hz}\end{array}$ & $\begin{array}{c}\text { Additional tests with } \\
\text { volunteers and ATDs, but } \\
\text { intervertebral rotation was } \\
\text { only measured with PMHS. } \\
\text { Only two vertebrae } \\
\text { measured (either C3/C6 or } \\
\text { C4/C7) }\end{array}$ & Yes & $\mathrm{S}$ & Yes & No & $\begin{array}{l}\text { Yes } \\
\text { but } \\
\text { only for } \\
2 \text { ver- } \\
\text { tebrae }\end{array}$ & No & No & No \\
\hline $\begin{array}{c}1997 \\
\text { Yale } \\
\text { University } \\
\text { School of } \\
\text { Medicine } \\
{[28,39,40]} \\
- \text { no } \\
\text { artificial } \\
\text { muscles }\end{array}$ & $\begin{array}{c}\text { PMHS- } \\
\text { specimens } \\
\text { (cleaned of } \\
\text { all non- } \\
\text { osteo- } \\
\text { ligament- } \\
\text { ous soft } \\
\text { tissues); } \\
6[28] \text { or } 8 \\
{[39,40]} \\
\text { subjects, } \\
\text { gender not } \\
\text { specified. } \\
\text { Volunteer; } \\
\text { inconsistent }\end{array}$ & $\begin{array}{c}\text { Motion- } \\
\text { monitoring } \\
\text { flags on each } \\
\text { vertebrae and } \\
\text { high speed } \\
\text { video camera; } \\
500 \mathrm{~Hz}\end{array}$ & $\begin{array}{l}\text { Half the specimens were } \\
\text { fixed at T1, the other half at } \\
\text { C7; use of artificial head. } \\
\text { Specimen study: no } \\
\text { horizontal of rotational } \\
\text { motion of lowest vertebrae; } \\
\text { no muscles included in } \\
\text { study }\end{array}$ & $\begin{array}{l}\text { Yes, but no } \\
\text { contact } \\
\text { mentioned }\end{array}$ & No seat & $\begin{array}{l}\text { Yes but } \\
\text { only for } \\
\text { one } \\
\text { speci- } \\
\text { men }\end{array}$ & No & $\begin{array}{l}\text { Yes but } \\
\text { only for } \\
\text { one } \\
\text { speci- } \\
\text { men }\end{array}$ & No & $\begin{array}{c}\text { No } \\
\text { Not } \\
\text { present } \\
\text { in study }\end{array}$ & $\begin{array}{l}\text { Yes but } \\
\text { only for } \\
\text { one } \\
\text { speci- } \\
\text { men }\end{array}$ \\
\hline $\begin{array}{c}1997 \\
\text { JARI study } \\
\text { - using } \\
\text { inclined } \\
\text { sled }[53-57]\end{array}$ & $\begin{array}{l}: 12 \text { males } \\
\& 8 \text { females } \\
{[53], 12} \\
\text { males }[54], \\
10 \text { males } \\
{[55,57] \text { or } 6} \\
\text { males }[56]\end{array}$ & $\begin{array}{c}\text { X-Ray; } \\
90 \mathrm{~Hz}[54-57]\end{array}$ & $\begin{array}{l}\text { Radiation dose: } 0.073 \mathrm{mGy} \\
\text { per frame and up to } 25 \\
\text { frames }[55,57] . \\
\text { Small field of view }(30 \mathrm{~cm} \\
\quad \text { x } 30 \mathrm{~cm})[54,56,57]\end{array}$ & No & $\mathrm{R}$ & $\begin{array}{c}\text { Yes } \\
\text { Gender } \\
\text { specific }\end{array}$ & $\begin{array}{c}\text { Yes } \\
\text { Gender } \\
\text { specific }\end{array}$ & $\begin{array}{c}\text { Yes } \\
\text { Gender } \\
\text { specific }\end{array}$ & $\begin{array}{c}\text { Partly } \\
\text { Only } \\
\text { for C3 } \\
\text { and C6 } \\
\text { [57] }\end{array}$ & $\begin{array}{c}\text { Yes } \\
\text { Gender } \\
\text { specific }\end{array}$ & $\begin{array}{c}\text { Yes } \\
\text { Gender } \\
\text { specific }\end{array}$ \\
\hline $\begin{array}{c}1998 \\
{[69,70]}\end{array}$ & $\begin{array}{l}\text { PMHS- } \\
\text { specimens; } \\
4 \text { subjects, } \\
\text { gender not } \\
\text { specified. }\end{array}$ & $\begin{array}{l}\text { visual targets } \\
\text { on vertebrae } \\
\text { and high } \\
\text { speed video } \\
\text { camera; } \\
\text { unspecified } \\
\text { frequency }\end{array}$ & $\begin{array}{c}\text { Head kinematics were } \\
\text { captures with high separate } \\
\text { speed camera }(4500 \mathrm{~Hz}), \\
\text { study focussed on } \mathrm{C} 5 / \mathrm{C} 6 \\
\text { facet joint. } \\
\text { Specimen study: no } \\
\text { horizontal of rotational } \\
\text { motion of lowest vertebrae; } \\
\text { lateral muscles removed }\end{array}$ & No & No seat & No & No & Yes & $\begin{array}{l}\text { Partly } \\
\text { Only } \\
\text { for } \\
\text { C5/C6 }\end{array}$ & $\begin{array}{c}\text { No } \\
\text { Not } \\
\text { present } \\
\text { in study }\end{array}$ & No \\
\hline $\begin{array}{c}1999 \\
{[15,48,} \\
49]\end{array}$ & $\begin{array}{l}\text { Full body } \\
\text { PMHS; } \\
3 \text { males } \\
\text { and } 3 \\
\text { females } \\
\text { (one male } \\
\text { PMHS } \\
\text { had both } \\
\text { arms and } \\
\text { legs } \\
\text { amputate } \\
\text { d) }\end{array}$ & $\begin{array}{l}\text { X-Ray with } \\
\text { additional } \\
\text { vertebrae } \\
\text { markers } \\
\text { (metal } \\
\text { spheres } \\
\text { with } 2 \mathrm{~mm} \\
\text { diameter); } \\
250 \mathrm{~Hz}\end{array}$ & $\begin{array}{l}\text { Additional displacement } \\
\text { and deformation of facet } \\
\text { capsules published; } \\
\text { results are published for } \\
\text { each PMHS individually. } \\
\text { Small field of view } \\
\text { (2D: } 25 \mathrm{~cm} \times 25 \mathrm{~cm}, 3 \mathrm{D} \text { : } \\
22.5 \mathrm{~cm} \times 17 \mathrm{~cm})\end{array}$ & $\begin{array}{l}\text { Test with } \\
\text { and } \\
\text { without } \\
\text { head } \\
\text { restraint }\end{array}$ & $\mathrm{R}$ & Yes & No & Yes & Yes & $\begin{array}{l}\text { No } \\
\text { but } \\
\text { relati } \\
\text { ve } \\
\text { C7 } \\
\text { rotati } \\
\text { on } \\
\text { avail } \\
\text {-able }\end{array}$ & Yes \\
\hline
\end{tabular}


Table A2 (continued)

\begin{tabular}{|c|c|c|c|c|c|c|c|c|c|c|c|}
\hline $\begin{array}{c}\text { Year and } \\
\text { Publication }\end{array}$ & $\begin{array}{c}\text { Subject } \\
\text { Type; } \\
\text { Number of } \\
\text { Subjects }\end{array}$ & $\begin{array}{l}\text { Measuring } \\
\text { Method; } \\
\text { Acquisition } \\
\quad \text { Rate }\end{array}$ & $\begin{array}{l}\text { Additional Information } \\
\text { and Limitations }\end{array}$ & $\begin{array}{c}\text { Head } \\
\text { Restraint }\end{array}$ & 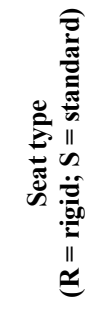 & 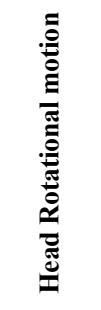 & 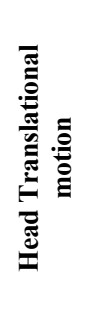 & 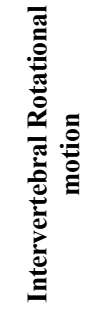 & 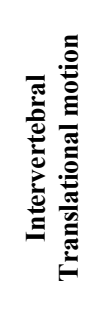 & 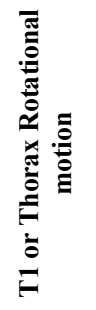 & 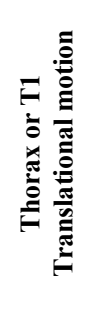 \\
\hline $\begin{array}{l}2000 \\
{[47]}\end{array}$ & $\begin{array}{l}\text { Full body } \\
\text { PMHS; } \\
3 \text { males }\end{array}$ & $\begin{array}{l}\text { Acceleration } \\
\text { sensors on } \\
\text { three } \\
\text { vertebrae } \\
(\mathrm{C} 2 / \mathrm{C} 5 / \mathrm{T} 1) \\
1000 \mathrm{~Hz}\end{array}$ & $\begin{array}{l}\text { Translational T1 motion is } \\
\text { presented in horizontal vs } \\
\text { vertical displacement } \\
\text { diagram, therefore not with } \\
\text { respect to time. } \\
\text { Only three vertebrae } \\
\text { instrumented; } \\
\text { PMHS do not represent } \\
50^{\text {th }} \% \text { male } \\
\text { Additional tests with }\end{array}$ & No & $\mathrm{R}$ & Yes & No & $\begin{array}{l}\text { Yes } \\
\text { but } \\
\text { only for } \\
\mathrm{C} 2, \mathrm{C} 5 \\
\text { and T1 }\end{array}$ & No & Yes & No \\
\hline $\begin{array}{c}\mathbf{2 0 0 3} \\
{[43,91]}\end{array}$ & $\begin{array}{c}\text { PMHS- } \\
\text { specimens; } \\
4 \text { males and } \\
7 \text { females }\end{array}$ & $\begin{array}{c}\text { Visual } \\
\text { markers on } \\
\mathrm{C} 3-\mathrm{T} 1 \text { and } \\
\text { high speed } \\
\text { video camera; } \\
1000 \mathrm{~Hz}\end{array}$ & $\begin{array}{c}\text { volunteer were performed } \\
\text { without intervertebral } \\
\text { motion. } \\
\text { Specimen study: no } \\
\text { horizontal of rotational } \\
\text { motion of lowest vertebrae; } \\
\text { no muscles included in }\end{array}$ & Yes & No seat & No & Yes & Yes & $\begin{array}{l}\text { Partly } \\
\text { Hori- } \\
\text { zontal } \\
\text { Yes; } \\
\text { Verti- } \\
\text { cal No }\end{array}$ & $\begin{array}{c}\text { Not } \\
\text { present }\end{array}$ & Yes \\
\hline $\begin{array}{c}\mathbf{2 0 0 3} \\
{[1,3,79]}\end{array}$ & $\begin{array}{c}\text { PMHS- } \\
\text { specimens; } \\
5 \text { males and } \\
5 \text { females }\end{array}$ & $\begin{array}{l}\text { visual targets } \\
\text { on each } \\
\text { vertebrae and } \\
\text { high speed } \\
\text { video camera; } \\
1000 \mathrm{~Hz} \text {, }\end{array}$ & $\begin{array}{l}\text { Study focussed on facet } \\
\text { joint; gender differences are } \\
\text { mentioned but not graphical } \\
\text { illustrated with respect to } \\
\text { time. } \\
\text { Specimen study: no } \\
\text { horizontal of rotational } \\
\text { motion of lowest vertebrae; } \\
\text { small amount of lateral } \\
\text { muscles removed }\end{array}$ & No & No seat & Yes & $\begin{array}{l}\text { Partly } \\
\text { Hori- } \\
\text { zontal } \\
\text { Yes; } \\
\text { Verti- } \\
\text { cal No }\end{array}$ & Yes & $\begin{array}{l}\text { Yes } \\
\text { but } \\
\text { only for } \\
\text { lower } \\
\text { spine } \\
\text { seg- } \\
\text { ments }\end{array}$ & $\begin{array}{c}\text { Not } \\
\text { present }\end{array}$ & No \\
\hline $\begin{array}{c}2004 \\
{[51]}\end{array}$ & $\begin{array}{l}\text { PMHS } \\
4 \text { females }\end{array}$ & $\begin{array}{l}\text { X-Ray with } \\
\text { additional } \\
\text { vertebrae } \\
\text { metal markers } \\
\text { with } 2 \text { mm } \\
\text { diameter; } \\
\text { X-ray } \\
\text { frequency } \\
\text { unknown }\end{array}$ & $\begin{array}{l}\text { Additional displacement } \\
\text { and deformation of facet } \\
\text { capsules published; detailed } \\
\text { results only for one PMHS. }\end{array}$ & Yes & $\mathrm{R}$ & $\begin{array}{l}\text { Only } \\
\text { relative } \\
\text { to C7 }\end{array}$ & No & Yes & No & No & $\begin{array}{l}\text { Partly } \\
\text { Hori- } \\
\text { zontal } \\
\text { Yes; } \\
\text { Verti- } \\
\text { cal No }\end{array}$ \\
\hline $\begin{array}{c}2004 \\
\text { Yale } \\
\text { University } \\
\text { School of } \\
\text { Medicine } \\
{[61,92]-} \\
\text { with } \\
\text { artificial } \\
\text { muscles } \\
{[38]}\end{array}$ & $\begin{array}{c}\text { PMHS- } \\
\text { specimens; } \\
4 \text { males and } \\
2 \text { females }\end{array}$ & $\begin{array}{c}\text { Visual targets } \\
\text { on } \mathrm{C} 2 \text { to } \mathrm{C} 7 \\
\text { and high } \\
\text { speed video } \\
\text { camera; } \\
500 \mathrm{~Hz}\end{array}$ & $\begin{array}{c}\text { Specimen study: no } \\
\text { horizontal of rotational } \\
\text { motion of lowest vertebrae; } \\
\text { specimens were cleaned of } \\
\text { all non-osteoligamentous } \\
\text { soft tissues; artificial } \\
\text { muscle force replications } \\
\text { were used to enhance the } \\
\text { specimen performance. }\end{array}$ & No & No seat & Yes & Yes & Yes & No & $\begin{array}{c}\text { No } \\
\text { Not } \\
\text { present }\end{array}$ & Yes \\
\hline
\end{tabular}


Table A3 (continued)

\begin{tabular}{|c|c|c|c|c|c|c|c|c|c|c|c|}
\hline $\begin{array}{c}\text { Year and } \\
\text { Publication }\end{array}$ & $\begin{array}{c}\text { Subject } \\
\text { Type; } \\
\text { Number of } \\
\text { Subjects }\end{array}$ & $\begin{array}{l}\text { Measuring } \\
\text { Method; } \\
\text { Acquisition } \\
\text { Rate }\end{array}$ & $\begin{array}{l}\text { Additional Information } \\
\text { and Limitations }\end{array}$ & $\begin{array}{c}\text { Head } \\
\text { Restraint }\end{array}$ & 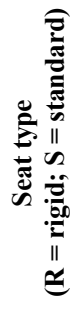 & 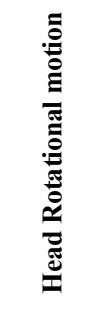 & 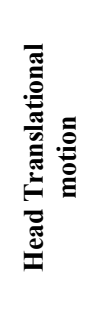 & 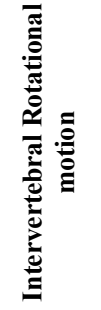 & 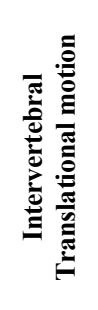 & 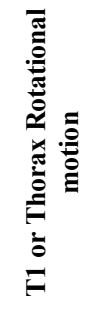 & 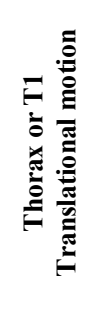 \\
\hline $\begin{array}{c}2006 \\
\text { JARI study } \\
\text { - using a } \\
\text { straight } \\
\text { sled [18, 52, } \\
53]\end{array}$ & $\begin{array}{l}\text { Volunteer; } \\
4 \text { males and } \\
2 \text { females } \\
\text { HUMON }\end{array}$ & $\begin{array}{c}\text { X-Ray; } \\
60 \mathrm{~Hz}\end{array}$ & $\begin{array}{c}\text { Capture of head and neck } \\
\text { motion with high speed } \\
\text { video camera (500 } \\
\text { frames/s); radiation dose: } \\
\text { 016mGy per frame and up } \\
\text { to } 20 \text { frames } \\
\text { Presumable small field of } \\
\text { view due to image } \\
\text { intensifier (not specified). } \\
\text { HUMON has unique }\end{array}$ & No & $\mathrm{R}$ & $\begin{array}{c}\text { Yes } \\
\text { Gender } \\
\text { specific }\end{array}$ & $\begin{array}{c}\text { Yes } \\
\text { Gender } \\
\text { specific }\end{array}$ & $\begin{array}{c}\text { Yes } \\
\text { Gender } \\
\text { specific }\end{array}$ & $\begin{array}{c}\text { Yes } \\
\text { Gender } \\
\text { specific }\end{array}$ & $\begin{array}{l}\text { No } \\
\text { but C7 } \\
\text { rotation } \\
\text { avail- } \\
\text { able, } \\
\text { gender } \\
\text { specific }\end{array}$ & $\begin{array}{c}\text { Yes } \\
\text { Gender } \\
\text { specific }\end{array}$ \\
\hline $\begin{array}{c}\mathbf{2 0 0 9} \\
{[41,42,59]}\end{array}$ & $\begin{array}{l}\text { (BIORID II } \\
\text { with PMHS } \\
\text { cervical } \\
\text { neck); } \\
2 \text { males and } \\
4 \text { females }\end{array}$ & $\begin{array}{l}\text { Visual } \\
\text { markers and } \\
\text { high speed } \\
\text { video camera; } \\
\quad 500 \mathrm{~Hz}\end{array}$ & $\begin{array}{l}\text { advantages and limitations } \\
\text { (see original publications). } \\
\text { Artificial head is stabilized } \\
\text { with muscle force } \\
\text { replications since muscles } \\
\text { had to be removed. }\end{array}$ & Yes & $\mathrm{S}$ & Yes & Yes & Yes & Yes & Yes & Yes \\
\hline $\begin{array}{l}2009 \\
{[50]}\end{array}$ & $\begin{array}{c}\text { Full Body } \\
\text { PMHS } \\
2 \text { males }\end{array}$ & $\begin{array}{l}\text { X-Ray, with } \\
\text { additional } \\
\text { vertebrae } \\
\text { metal markers } \\
\text { with } 2 \mathrm{~mm} \\
\text { diameter; } \\
\text { The output of } \\
\text { the intensifier } \\
\text { was recorded } \\
\text { at } 1,000 \text { fps } \\
\text { with } 200- \\
\text { microsecond } \\
\text { exposure }\end{array}$ & $\begin{array}{l}\text { Same sled apparatus as } \\
\text { Deng [49]. } \\
\text { Pelvis also recorded and } \\
\text { movement presented. } \\
\text { Small field of view: } 30 \mathrm{~cm} \\
\text { image intensifier. High } \\
\text { speed video data and the } \\
\text { high speed X-ray data could } \\
\text { not be collected during the } \\
\text { same test }\end{array}$ & $\begin{array}{c}\text { Test with } \\
\text { and without } \\
\text { head } \\
\text { restraint }\end{array}$ & $\mathrm{R}$ & Yes & Yes & Yes & No & $\begin{array}{c}\text { Yes, } \\
\text { for } 8 \\
\text { and } 16 \\
\mathrm{~km} / \mathrm{s}\end{array}$ & $\begin{array}{c}\text { Yes, } \\
\text { for } 8 \\
\text { and } 16 \\
\mathrm{~km} / \mathrm{s}\end{array}$ \\
\hline $\begin{array}{l}2014 \\
{[60]}\end{array}$ & $\begin{array}{l}\text { Full body } \\
\text { PMHS; } \\
7 \text { males } \\
\\
\\
\text { Full body } \\
\text { PMHS; } \\
2 \text { males and } \\
2 \text { females }\end{array}$ & $\begin{array}{c}3 \text { acceleration } \\
\text { sensors and } 3 \\
\text { angular rate } \\
\text { sensors for C2 } \\
\text { to C7; } \\
12.5 \mathrm{kHz} \\
\\
\\
\text { X-Ray with } \\
\text { additional } \\
\text { vertebrae } \\
\text { metal marker } \\
\text { (screw); } \\
500 \mathrm{~Hz}\end{array}$ & $\begin{array}{l}\text { Each PMHS was tested at } \\
\text { different test conditions } \\
\text { (seat and acceleration pulse } \\
\text { varied). This may be the } \\
\text { reason why the PMHS } \\
\text { responses have a wide } \\
\text { range, but can also be } \\
\text { attributed to different } \\
\text { PMHS behaviour. } \\
\text { Main focus on females. } \\
\text { Image intensifier of } \\
\text { approximately } 400 \text { mm } \\
\text { diameter, field of view for } \\
\text { cervical spine not specified. } \\
\text { Intervertebral data is } \\
\text { presented in horizontal vs } \\
\text { vertical displacement } \\
\text { diagram, therefore not with } \\
\text { respect to time. }\end{array}$ & $\begin{array}{c}\text { Test with } \\
\text { and without } \\
\text { head } \\
\text { restraint }\end{array}$ & $\mathrm{S}$ & Yes & Yes & Yes & Yes & Yes & Yes \\
\hline
\end{tabular}

